\title{
Thermal Comfort Assessment and Characteristics of Occupant's Behavior in Naturally Ventilated Buildings in Composite Climate of India

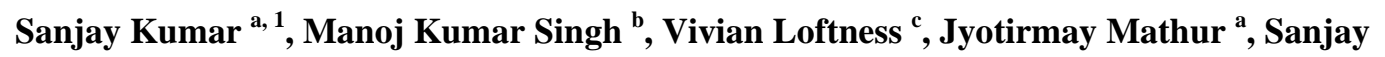 Mathur $^{\text {a }}$
}

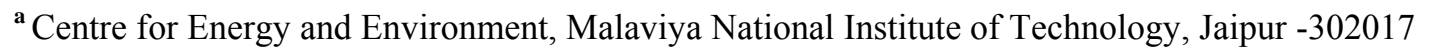 \\ India \\ ${ }^{\mathbf{b}}$ Department of Human and Social Systems, Institute of Industrial Science, The University of Tokyo, \\ Tokyo 153-8505, Japan \\ ${ }^{\mathrm{c}}$ School of Architecture, Carnegie Mellon University, Pittsburgh, PA 15213
}

\begin{abstract}
Energy consumption in Indian building sector is increasing at high rate. The National Building Code of India specifies a narrow comfort temperature range between $21{ }^{\circ} \mathrm{C}$ and $26{ }^{\circ} \mathrm{C}$ for all types of buildings and for all seasons. A thermal comfort field study was conducted in 32 naturally ventilated buildings, collecting a total of 2610 samples spread over a total period of four years, covering multiple seasons, age groups, clothing types and building types. Questionnaires were administered to building occupants to record sensations and preferences for air temperature, relative humidity and air velocity on ASHRAE seven point and five point scales. The objective of the study was to evaluate thermal comfort of occupants and study the methods of thermal adaptation such as adjusting clothing, window opening, and use of air circulation fans. Griffith's method was used to determine thermal neutrality. The comfort temperature for summer and winter season was found to be $30.6{ }^{\circ} \mathrm{C}$ and 25.2 ${ }^{\circ} \mathrm{C}$, respectively. Preferred clothing level for summer was found to be $0.30 \mathrm{clo}$, whereas in winter it was 0.80 clo. Preferred air velocity was observed as $0.62 \mathrm{~m} / \mathrm{s}$ in summer season and $0.27 \mathrm{~m} / \mathrm{s}$ in winter. Controlling air velocity has been found to be preferred method of thermal adaptation over adjusting clothing and window opening.
\end{abstract}

Keywords: Thermal environment; Comfort temperature; Thermal adaptation; Naturally ventilated buildings; Composite climate

\footnotetext{
${ }^{1}$ Corresponding author: Present Address: Centre for Energy and Environment, Malaviya National Institute of Technology, Jaipur -302017 India

E-mail address: sanjuhissar@gmail.com
} 


\section{Introduction}

The internationally accepted standard for defining thermal comfort conditions [1, 2], is based on Fanger's heat balance model of the human body. This heat balance model, also called PMV(Predicted Mean Vote) / PPD (Percentage People Dissatisfied) model, is among the most widely accepted models for building thermal design and determination of thermal comfort conditions especially in air conditioned spaces. The evidence of critical role played by psychological, physiological and sociocultural aspects of adaptation in defining comfort standards has lead researchers to question the universal applicability of uniform comfort conditions suggested by these standards [3-6].

An alternative to the PMV/PDD model is the adaptive model, which is based on the results of field studies conducted since 1960's [7-8]. According to the adaptive hypothesis, contextual factors and past thermal history modify the occupant's thermal expectations and preferences. Currently, the adaptive model is widely accepted as efficient tool in predicting indoor comfort conditions for naturally ventilated buildings $[1,3,9]$.

The National Building Code of India of 2005 [10] defines two indoor temperature ranges, for summer $23^{\circ} \mathrm{C}-26^{\circ} \mathrm{C}$ and winter $21^{\circ} \mathrm{C}-23{ }^{\circ} \mathrm{C}$. These are supposed to be applicable for conditioned as well as naturally ventilated buildings.

Sharma and Ali [11] carried out thermal comfort study in tropical climate of India and reported high comfort temperature range $\left(25^{\circ} \mathrm{C}-30^{\circ} \mathrm{C}\right)$.

Indraganti [12] carried out thermal comfort field study in naturally ventilated apartment and found a neutral temperature of $29.2{ }^{\circ} \mathrm{C}$ for studied subjects in summer season.

Singh et al. [13] carried out a field study for vernacular architecture of North-Eastern India for three climatic zones and demonstrated seasonal and regional differences in neutral temperature.

Dhaka et al. [14] carried out a thermal comfort study for naturally ventilated buildings in composite climate of Jaipur and found a neutral temperature of $27.2{ }^{\circ} \mathrm{C}$ for all seasons. This study was conducted mainly with young subjects. Differences in age were not considered. Moreover this study did not include analysis of occupant behavior and adaptation.

It has been found that most of the studies conducted in India so far had carried out data collection from one particular building type, including study conducted by Sharma and Ali [11], Indraganti [12] and Singh [13]. Even the recent work for project IMAC (Indian model for adaptive thermal comfort) [15], only included office buildings, and is carried out with very limited surveys from four months of the year. 
Research on adaptive comfort, specifically in warm to hot climates, has revealed that occupants in naturally ventilated buildings are more tolerant towards high fluctuations encountered in indoor environmental conditions $[11,16,17]$.

In a naturally ventilated building, occupants use several adaptive opportunities and controls such as operable windows, doors, blinds, curtains, fans \& fan regulator for adjustment of air velocity to make themselves comfortable in the changing thermal environment. Uses of these adaptive controls are also affected by seasonal and climatic variation in indoor conditions [18-21].

Most of the current research in other countries is aiming at the prediction of occupant behavior and use of various controls; simultaneously developing algorithms of occupant's controls. Algorithms developed through such studies can be utilized for simulation of buildings [22]. However, a very few studies have been reported for the use of various behavioral controls in residential and educational environments from Indian building sector in recent years [23, 24].

Present study was conducted to find out range of neutral temperature specific to naturally ventilated buildings in composite climate and occupants behaviour in the context of control strategies. This paper summarizes a thermal comfort field study conducted in 32 naturally ventilated buildings in composite climate zone of India.

\section{Methodology}

\subsection{Description of field study}

The field study of thermal comfort was performed in the composite climate of Jaipur $\left(26.82^{\circ} \mathrm{N}, 75.80\right.$ ${ }^{\circ} \mathrm{E}$ and $390 \mathrm{~m}$ mean sea level) for 14 offices and 18 residential buildings for a period of four years (April, 2011-July, 2015). Figure 1 shows the overview of the methodology of this study. Meteorological conditions under this climate vary from extremely hot during summer to chilling cold during winter. Summer peak temperature soars above $45^{\circ} \mathrm{C}$, and then falls to about $4{ }^{\circ} \mathrm{C}$ in winter. Due to this large variation, months across the year are segregated into three categories, namely, summer, moderate, and winter. In the present study, a particular month is considered winter if the daily mean outdoor temperature varied between $4{ }^{\circ} \mathrm{C}-25{ }^{\circ} \mathrm{C}$ for minimum 20 equivalent days (480 hours). Likewise, a particular month is considered summer if daily mean outdoor temperature was more than $27{ }^{\circ} \mathrm{C}$ for more than or equal to 20 equivalent days. If any month, is neither winter nor summer as per above criteria, it is considered as moderate [14, 25]. This approach was adopted for categorization of climatic zones of India that are presented in the National Building Code of India and Energy Conservation Building Code [10, 26]. 
Following this approach, in Jaipur, the summer season is of six months (April-September), winter of four months (November-February), separated by the moderate season of two months (March and October). The present thermal comfort surveys were conducted covering multiple seasons.

Figure 1

\subsection{Building selection and data collection}

In this study, the buildings were named as $\mathrm{O} 1-\mathrm{O} 14$ for office stock and R15-R32 for residential stock. These buildings lie within a radius of $10 \mathrm{~km}$ in Jaipur city. Table 1 presents the details of the buildings, mode of operation, ownership and subjects who participated in the study. In these buildings walls were constructed of brick/stone walls of $0.20-0.23 \mathrm{~m}$ and roofs of Reinforced Cement Concrete (RCC) were used. Window assemblies were largely, single clear glass panes of 4-8 mm thickness, except a few newer buildings that have doubled glazed windows. The surveyed buildings were naturally ventilated and provide opportunities for use of adaptive controls to the occupants such as opening or closing of windows and doors, control of ventilators, operation of fan and fan speed regulators, etc.

\section{Table 1}

The transverse type questionnaire was used as per the study conducted by Dhaka et al. [23]. Section-A of the questionnaire consists of thermal sensation and preference votes for environment conditions such as air temperature, relative humidity, air velocity and lighting on ASHRAE sevenpoint sensation and five-point preference scales. Section-B of the survey form was used to measure the environmental parameters and the environmental conditions surrounding the study subjects.

A brief introduction was given to subjects before they started filling the questionnaire to minimize the chances of human error in understanding the purpose of survey. While subjects were responding to the questionnaire, environmental parameters, personal parameters and environmental controls in subject's surroundings were recorded. During the survey, care was taken that the functioning conditions of the building and occupants' settings are not modified.

\subsection{Measurement of indoor and outdoor environment}

Physical measurements of environment variables were recorded surrounding the subject using high accuracy instruments. The measurements were taken at a height of $1.1 \mathrm{~m}$ above the ground level following the Class-II protocol $[1,2]$. The measurement of environmental parameters such as air temperature, globe temperature, air velocity, and personal variables such as clothing level and metabolic activity $\left(T_{a}, T_{g}, V_{a}, R H\right.$, clo, met) were recorded at the same time and place when the questionnaire was administered to the subjects. Table 2 demonstrates the details of instruments used 
in this study to measure the indoor conditions. Outdoor environmental data consisting of temperature and relative humidity for entire period of study was recorded from a weather station located at MNIT, Jaipur, India.

Table 2

\subsection{Sample size and description}

The subjects were all Indian nationals well acclimatized to the composite climate of Jaipur for more than one year and were in the age group of 18-70 years. Each subject participated in the survey after he/she had settled in the environment for more than 20 minutes. The sample size varied across the seasons and a total of 2610 fully completed survey forms were obtained including responses from 2013 males and 597 females.

For clothing insulation and metabolic rates, we used the standard checklists provided in ASHRAE 55 [1]. Clo-values for Indian women clothing including the cotton salwar-kameej, saari, etc. are not available in ASHRAE 55 and ISO 7730, were taken from other India specific studies [12, 27]. The mean activity of the subjects was observed to be nearly sedentary activity, i.e. 1.06 met (1 met $=58.2 \mathrm{~W} / \mathrm{m}^{2}$ ) and it shows that the subjects were mostly seated or doing light office work. A detailed description of sample size; each subject's physical characteristics such as age, weight, body surface area, clothing insulation and activity level has been recorded for all seasons and is presented in Table 3.

Table 3

\section{Results \& Discussion}

\subsection{Assessment of indoor and outdoor thermal environment}

During the field study period, minimum and maximum outdoor dry bulb temperatures were $12^{\circ} \mathrm{C}$ and $45^{\circ} \mathrm{C}$. Room air temperature varied between $14.4^{\circ} \mathrm{C}$ to $39.1^{\circ} \mathrm{C}$ and relative humidity was recorded between $8 \%$ to $96 \%$. Figure 2 shows the details of environmental parameters observed, viz. mean daily outdoor temperature, mean daily indoor operative temperature and mean daily indoor relative humidity for the whole study period.

\section{Figure 2}

The naturally ventilated buildings experience a higher fluctuation in mean indoor temperature, from winter (Mean $\mathrm{T}_{\mathrm{op}}=22.1^{\circ} \mathrm{C}, \mathrm{SD}=3.60$ ) to moderate $\left(\right.$ Mean $\mathrm{T}_{\mathrm{op}}=29.2^{\circ} \mathrm{C}, \mathrm{SD}=2.89$ ) to summer (Mean $\mathrm{T}_{\mathrm{op}}=31.8^{\circ} \mathrm{C}, \mathrm{SD}=2.86$ ) during the study period. Subjects in naturally ventilated buildings are more responsive to various adaptive actions, viz. changing clothing level, the opening of 
window and doors, using fans to maintain comfort, and this phenomenon is more pronounced at the higher temperatures and relative humidity in the summer season. Correspondingly, the mean air velocity was observed to be higher during the summer (Mean $\mathrm{V}_{\mathrm{a}}=0.62 \mathrm{~m} / \mathrm{s}, \mathrm{SD}=0.39$ ) than during the moderate season (Mean $\mathrm{V}_{\mathrm{a}}=0.57 \mathrm{~m} / \mathrm{s}, \mathrm{SD}=0.37$ ) and winter (Mean $\mathrm{V}_{\mathrm{a}}=0.27 \mathrm{~m} / \mathrm{s}, \mathrm{SD}=0.19$ ), respectively. Table 4 shows the statistical analysis of seasonal variation in outdoor and indoor variables observed during the field study.

\section{Table 4}

\subsection{Subjective thermal variables: Evaluation of sensation and preferences}

\subsubsection{Sensation and preference for temperature (TSV \& TPV)}

Through the comfort survey questionnaire, thermal sensation of the building occupants was accessed using the question "How do you feel the temperature right now?" Figure 3 shows the distribution of subject responses collected during summer, moderate and winter season, respectively. About 79\%, $92 \%$, and $70 \%$ of the subjects responses were found in comfort band ( \pm 1 sensations) in summer, moderate and winter season, respectively. A total of $82 \%$ of the subjects felt comfortable (including \pm 1 sensations) at prevailing indoor temperature conditions.

Figure 3

Table 5 presents the statistical analysis of sensation and preference votes of the building occupants on a seasonal basis. Following observations can be made from Table 5:

- Over an annual cycle, average thermal sensation varied between slightly warm to slightly cool.

- Mean value of sensation votes on an annual basis, combined for all seasons, was found slightly higher than neutral in naturally ventilated buildings (Mean Thermal Sensation Vote, $\mathrm{TSV}=+0.16, \mathrm{SD}=1.24)$.

- During the summer season, the mean thermal sensation was higher than neutral but less than slightly warm (Mean TSV $=0.67, \mathrm{SD}=0.92$ )

- During winter, it was lower than neutral but less than slightly cool (Mean $\mathrm{TSV}=-0.75, \mathrm{SD}=0.76)$.

\section{Table 5}

In response to thermal sensations recorded, the corresponding thermal preferences were captured with the question "How would you prefer to feel?" Figure 4 shows a cross-tabulated summary of thermal preference votes and thermal sensation votes. Figure 4 also shows that about 
$51 \%$ subjects reported the temperature neutral at the time of voting and want no change in temperature. It can be observed from the Table 5 that the preference for a cooler environment dominates across the seasons, with a mean value of $-0.22(\mathrm{SD}=0.92)$. Using the scale described above, the mean preference for temperature change was $-0.84(\mathrm{SD}=0.66)$ in summer, $-0.51(\mathrm{SD}=0.78)$ in moderate seasons and $+0.37(\mathrm{SD}=0.80)$ in winter. This pattern corroborates with the findings of Fountain et al. [28].

\section{Figure 4}

\subsubsection{Sensation and preference for humidity (HSV \& HPV)}

Relative humidity during the study was found varying between $8 \%$ and $96 \%$. Sensation for humidity and preferences were asked on seven points and five points scale respectively, as suggested by ASHRAE 55. Following observations can be made:

- $52 \%$ of subjects found humidity between $32 \%-38 \%$ acceptable at prevailing indoor humidity conditions.

- Mean humidity sensation (HSV) for all data sets in all naturally ventilated buildings was $+0.13(\mathrm{SD}=1.09)$ at a mean relative humidity of $43 \%$.

- Mean humidity sensation for summer, moderate, and winter season was found to be $+0.21(\mathrm{SD}=1.26),-0.23(\mathrm{SD}=0.87)$, and $-0.35(0.82)$, respectively.

- Mean humidity of $47 \%, 33 \%$, and $43 \%$ was observed for summer, moderate, and winter season, respectively (Table 5).

Figure 5 shows the cross tabulated summary for humidity sensation votes and humidity preferences votes. A maximum of $65 \%$ subjects accept the prevailing humidity conditions during the study and prefer no change in humidity. $18 \%$ subjects did not prefer any change while having 'slightly dry' sensation for humidity. Similarly, $10 \%$ did not prefer any change while having 'slightly humid' humidity sensation. The reason for such preferences could be expectancy and acceptance of such conditions that prevail in this climatic region.

\section{Figure 5}

\subsubsection{Sensation and preference for air velocity (AVS \& AVP)}

In the surveys, mean air velocity was found higher as the season got warmer. It was observed as 0.27 $\mathrm{m} / \mathrm{s}$ during winter, $0.57 \mathrm{~m} / \mathrm{s}$ during moderate and $0.62 \mathrm{~m} / \mathrm{s}$ during the summer season. The corresponding occupant mean sensation of air velocity for the different seasons was $-0.35(\mathrm{SD}=1.09)$ in summer, $-0.25(\mathrm{SD}=1.01)$ in moderate seasons and $-0.10(\mathrm{SD}=0.62)$ in winter. 


\section{Figure 6}

Figure 6 represents the distribution of air velocity sensation votes compared to measured air velocities prevailing inside the surveyed buildings. The study shows a large variation in air velocity measurements across the sensation votes. Figure 7 reveals that as temperatures rise from winter to summer, the preference for more air velocity increases. This corroborates with other studies conducted in hot and humid countries, reporting that inhabitants in hot and warm countries prefer higher air velocity to make themselves comfortable at higher temperatures [11, 29-31]. It can be clearly seen from Figure 7 that most of the subjects preferred to have higher air velocity than prevailing indoor air velocity. This trend can also be visualized in a mean air velocity preference vote shown in Table 5. The mean air velocity preference votes were 0.67 in summer, 0.61 in moderate seasons and 0.20 in winter, respectively. A total of $64 \%$ subjects preferred to stay at the prevailing air velocity conditions.

\section{Figure 7}

\subsection{Comfort temperature}

\subsubsection{Linear Regression method}

The comfort temperature is known to be varying across the seasons [3]. Linear regression between subject's thermal sensation votes and corresponding room temperatures was performed in two ways. First, collectively for all the data sets over the year, and then separately for each of the three seasons, as shown in Table 6.

For combined year round analysis, a neutral temperature of $27.2{ }^{\circ} \mathrm{C}$ has been found as shown in Figure 8. A comfort band of $21.0^{\circ} \mathrm{C}-33.1{ }^{\circ} \mathrm{C}$ (i.e. corresponding to the TSV of -1 to +1 ) is obtained through the results of regression analysis. The slope of the Equation (1) is $0.15^{\circ} \mathrm{C}^{-1}$ indicating that for every $6.7^{\circ} \mathrm{C}$ change in indoor temperature, thermal sensation vote would have a unit change. Lower slope is also indicative of higher adaptation of the subjects to the indoor conditions encountered. A similar slope of $0.19^{\circ} \mathrm{C}^{-1}$ and a comfort band of $13{ }^{\circ} \mathrm{C}$, was obtained by Nicol and Roaf [32] for a study conducted in Pakistan, which has quite similar climatic and cultural background. Karyono [33] noted a slope of $0.32{ }^{\circ} \mathrm{C}^{-1}$ in Thai offices; Indraganti [12] recorded $0.31{ }^{\circ} \mathrm{C}^{-1}$ in the residential environments in Hyderabad for their comfort studies. Zhang et al. [34] observed a slope of $0.25{ }^{\circ} \mathrm{C}^{-1}$ during a thermal comfort study for naturally ventilated and air-conditioned buildings in humid subtropical climate zone in China.

$$
T S V=0.15 T_{o p}-4.05 \quad\left(R^{2}=0.56, S . E .=0.001, p<0.001\right)
$$


where TSV is Thermal Sensation Vote, $\mathrm{T}_{\mathrm{op}}$ is indoor operative temperature, S.E.is standard error, and $\mathrm{p}$ is significance level for linear regression method.

\section{Figure 8}

\section{Table 6}

\subsubsection{Griffith's comfort temperature}

Some researchers have pointed out issues with applying the regression method in the presence of adaptive behavior. It has been stated that the presence of behavioral adaptation in the data tends to artificially lower the regression coefficients and therefore the estimates of the comfort temperature [35- 37].Also, the mean comfort vote which is much different from the neutrality (Table 6), may also adversely affect the predictive power of the resultant regression equation. Hence, survey results of this study have again been used to re-estimate the comfort temperature using Griffith method as given below through Equation (2).

$$
\boldsymbol{T}_{C}=\boldsymbol{T}_{g}+(\mathbf{0}-\boldsymbol{T S V}) / \boldsymbol{G}
$$

where $\mathrm{T}_{\mathrm{c}}$ is the comfort temperature $\left({ }^{\circ} \mathrm{C}\right), \mathrm{T}_{\mathrm{g}}$ is the indoor globe temperature $\left({ }^{\circ} \mathrm{C}\right)$, TSV is the thermal sensation vote and $\mathrm{G}$ is the Griffith constant $\left(0.50^{\circ} \mathrm{C}^{-1}\right)$.

In applying the Griffith's method, Nicol and Humphreys et al. [8,37] used the constants 0.25 , 0.33 and 0.50 for a seven-7 point thermal sensation scale. Upon applying each of the three coefficients, it has been observed that there is hardly any change in the mean comfort temperature with each coefficient (Table 7). Analysis of mean indoor globe temperature for neutral votes on the sensation scale has shown close agreement with comfort temperature while using the Griffith method with $0.50{ }^{\circ} \mathrm{C}^{-1}$ as Griffith's coefficient. Therefore, Griffiths' comfort temperature, $\mathrm{T}_{\mathrm{c}}$, obtained using $0.50{ }^{\circ} \mathrm{C}^{-1}$ (with least standard deviation as shown in Table 7) is used in the subsequent analysis. The comfort temperature calculated using a coefficient of 0.50 is indicative of a $2{ }^{\circ} \mathrm{C}$ rise for unit perturbation in sensation vote, which is smaller as compared to linear regression approach applied in this study as well as other similar studies.

\section{Table 7}

The mean indoor globe comfort temperature by Griffith's method is $27.9{ }^{\circ} \mathrm{C}$ in naturally ventilated buildings. The finding is in close agreement with the neutral operative temperature observed in Singapore: $28.5^{\circ} \mathrm{C}$ [38], and Hyderabad: $28.0^{\circ} \mathrm{C}$ [12] in natural ventilated buildings. 


\subsubsection{Comfort temperature: Seasonal variation.}

Seasonal variation in comfort temperature was also noticed from summer to winter season. The comfort temperature variations were observed across season as well as within one season (Figure 9). The results show that comfort temperature is related to the change in outdoor air temperature, which in composite climate of Jaipur is very high $\left(\sim 45^{\circ} \mathrm{C}\right)$ during summer to appreciably low in winter $(\sim 4$ ${ }^{\circ} \mathrm{C}$ ). Singh et al. [39] for their field study of vernacular residential buildings in North-East region of India has also reported similar results.

The mean comfort temperature calculated using Griffith's method is $30.6{ }^{\circ} \mathrm{C}$ in summer, $29.5{ }^{\circ} \mathrm{C}$ in moderate and $25.2{ }^{\circ} \mathrm{C}$ in winter, respectively in naturally ventilated buildings. Thus, the seasonal variation of mean comfort temperature is about $5.4^{\circ} \mathrm{C}$.

Figure 9

\subsection{Analysis of occupant behavioural adaptation}

Adaptive thermal comfort is based on the fundamental assumption that "if a change produces discomfort; people react in ways which tend to restore their comfort" [8]. Behavioural use of controls is interconnected with the physiology/psychology of the body and physics of the buildings [18, 19]. In this study, behavioural adaptations at personal level have been analysed, viz. changing clothing levels, use of personal environmental controls like the opening of window/door (for the natural flow of air) and use of a fan(for forced airflow); to make the surrounding environment comfortable.

\subsubsection{Adaptation through clothing}

The mean values of clothing were found a bit higher for female occupants than male occupants across all seasons. Clothing values continuously increased from the summer (Mean clo $=0.34, \mathrm{SD}=0.15$ ) to winter season (Mean clo $=0.67, \mathrm{SD}=0.14$ ), revealing continuous adaptation by occupants through adjusting clothing patterns. Clothing level variations were recorded for each season across the multiple years of study. Clothing levels have been plotted against instantaneous outdoor temperature for winter, moderate and summer seasons in Figure 10(a, b, and c), respectively. This data presents an important characterization of continuous adaptation by building occupants that is taking place season by season. The temperature corresponding to inflexion points (maximum and minimum temperatures) have been noticed as being common between two adjoining seasons, i.e. summer to moderate and moderate to winter. This shows that clothing is the principal adaptive opportunity available to occupants to overcome seasonal discomfort. The most preferred clothing level for summer was found to be 0.30 clo, for moderate 0.40 clo and 0.80 clo for winter season of composite climate in India. 
To study the dependence of clothing level on outdoor temperature, linear and polynomial regression analysis was carried out for different seasons. Equations (3) to (5) represent the polynomial regression for summer, moderate and winter season, respectively.

$$
\begin{array}{ll}
\text { Clo }=0.0005 \times \mathrm{T}_{0}{ }^{2}-0.049 \times \mathrm{T}_{0}+1.35 & \left(\mathrm{R}^{2}=0.35\right) \\
\text { Clo }=0.0008 \times \mathrm{T}_{0}{ }^{2}-0.064 \times \mathrm{T}_{0}+1.55 & \left(\mathrm{R}^{2}=0.50\right) \\
\text { Clo }=0.0018 \times \mathrm{T}_{0}{ }^{2}-0.118 \times \mathrm{T}_{0}+2.28 & \left(\mathrm{R}^{2}=0.65\right)
\end{array}
$$

A similar analysis for correlation of clothing insulation and outdoor temperature was carried out by Leow and de Dear [38], Singh et al.[40] and Mui and Chan [41]. This study revealed higher coefficient of correlation for clothing insulation with outdoor temperature than what Mui and de Dear had observed in their field study. As evident from Figure 10 (a, b, c), the polynomial regression was found to be more appropriate as compared to the linear regression for capturing variation in region specific clothing.

Figure 10

\subsubsection{Use of controls: Window, External door and Fan}

In Section-B of questionnaire, adaptive behavior for use of controls such as adjusting opening of windows, curtains and other electrical controls such as adjusting operation of fans was noted as binary data (0: not in use/closed; 1: in use/ open). The mean proportion of windows and doors open to external environment were found to be 0.56 and 0.64 during summer season and relatively low in winter season 0.27 and 0.40 , respectively. Least open windows and doors were found during peak summer months (April-June) as outdoor conditions are very harsh, and entry of very hot outdoor air adds to occupant discomfort. Also, during rainy season (July \& August), despite relatively low air temperature, to prevent entry of mosquitoes and insects breeding, only a limited use of windows is observed. Significant fraction of windows closed during summer season suggests that there might be other more influencing reasons for opening/closing of windows such as noise, pollution, safety.

The window opening trend, use of fan, and mean air velocity (at 95\% confidence interval) observed in naturally ventilated spaces across all season and months is shown in Figure 11.

Figure11

\subsubsection{Window opening behavior in respect to outdoor temperature and indoor temperature}

To analyze the window opening behavior in built environment; the data were divided into ten groups called Deciles (ranked and aggregated group of data), in an ascending order of temperature as shown 
in Table 8. In present study $40 \%$ of total observation, windows were found open (Mean $\mathrm{P}_{\mathrm{w}}=0.40$, $\mathrm{N}=2610$ ). The proportion of the window opening rises as the indoor globe or outdoor air temperature rises as shown in figure 12.

\section{Table 8}

\section{Figure12}

When mean indoor globe temperature and outdoor air temperature are $28.5^{\circ} \mathrm{C}$ and $28.7^{\circ} \mathrm{C}$, the proportion of open windows were 0.50 and 0.57 respectively. The findings for window openings are similar to Nicol and Rijal [19] in their Pakistan study, but lower than that of European subjects in office buildings [21]. Also, a study for residential buildings in summer and monsoon season of Hyderabad, about $40 \%$ of windows were found open at same prevailing conditions [20, 24]. People opened the windows in response to the increase in the indoor and outdoor temperatures and reaches to a maximum of $75 \%$ when mean indoor globe temperature peaks at $33.5{ }^{\circ} \mathrm{C}$. Explaining this phenomenon, Rijal et al. [21] and Indraganti et al. [42] observed that the indoor climate, the outdoor climate and a mixture of both might drive the use of controls. Results also reveal that proportion of window open $\left(\mathrm{P}_{\mathrm{w}} \%\right)$ correlate significantly $(\mathrm{p}<0.01)$ with both indoor globe and outdoor air temperature (Table 9).

\section{Table 9}

\subsubsection{Use of Ceiling Fans}

Nicol [20] for a study conducted for buildings of Roorkee (India) and Bagdad (Iraq), that air velocities up to $1.5 \mathrm{~m} / \mathrm{s}$ were acceptable for subjects in hot and warm countries. Figure 13 shows the use of fan with decile of indoor globe temperature. The use of fans significantly increased with the rise in indoor temperature (Pearson's correlation $\mathrm{r}=0.76, \mathrm{~N}=2628, \mathrm{p}<0.01$ ). Also, Pearson correlation $(\mathrm{r}$ ) for the fan use is higher than window, indicating fan come into use over a narrow range of indoor air temperature. This indicates controlling air velocity found to be preferred method of thermal adaptation over adjusting clothing and window opening in composite climate of Jaipur.

The proportion of fans in use ( $\mathrm{Pf} \%$ ) reached a maximum of $81 \%$ when the mean indoor temperatures peaked at $28.5{ }^{\circ} \mathrm{C}$. Similarly, Rijal et al. [19] noted around $81 \%$ 'fans on' at an indoor temperature of $30{ }^{\circ} \mathrm{C}$, in Pakistan. Subjects in present study are found to have $3{ }^{\circ} \mathrm{C}$ higher comfort temperature $\left(\mathrm{T}_{\mathrm{c}}\right)$ under 'fan on' use than when 'fan was off' $\left(29.6^{\circ} \mathrm{C}\right.$ as against $\left.26.6^{\circ} \mathrm{C}\right)$.

Figure 13 


\section{Conclusion}

This paper summarizes the findings of a thermal comfort field study conducted in 32 naturally ventilated buildings in the composite climate of Jaipur. A total of 2610 data sets were collected spread over a total period of four years, covering multiple seasons, age groups, clothing types and building types. The questionnaires were used to collect the sensations and preferences of subject related to room temperature, relative humidity, air velocity and overall comfort. Simultaneously, the environmental conditions surrounding the subjects were recorded considering Class-II protocol of field measurement. The results from this adaptive comfort study reveal range of thermal parameters for comfort, occupant expectations, seasonal clothing adaptations and use of various controls.

Key conclusions of the study are as follows:

1. A total of $82 \%$ of the subjects felt thermally comfortable ( \pm 1 sensations) at prevailing indoor conditions. The mean value of sensation votes for all seasons was found slightly higher than neutral in naturally ventilated buildings.

2. Mean air velocity increases as the season gets warmer. It has been observed as $0.27 \mathrm{~m} / \mathrm{s}$ in winter, and $0.62 \mathrm{~m} / \mathrm{s}$ in summer. The corresponding occupant mean sensation of air velocity for the different seasons was -0.35 in summer and -0.10 in winter. This reflects typical high air velocity preference of Indian subjects living in composite climatic conditions.

3. On annual basis, the mean comfort temperature, as predicted by Griffith's method, was found to be $27.9^{\circ} \mathrm{C}$.

4. Seasonal analysis reveals, the mean comfort temperature is $30.6{ }^{\circ} \mathrm{C}$ in summer and $25.2{ }^{\circ} \mathrm{C}$ in winter, respectively. Thus, the seasonal variation of mean comfort temperature is about $5.4{ }^{\circ} \mathrm{C}$ as obtained through Griffith's method.

5. In naturally ventilated buildings of this climate, there is a continuous adaptation in clothing pattern throughout the year, affecting occupant sensations and preferences. The most preferred clothing level for summer is 0.30 clo and 0.80 clo for winter in composite climate of Jaipur.

6. The proportion of window opening reaches to a maximum of $75 \%$ when mean indoor globe temperature peaks at $33.5^{\circ} \mathrm{C}$.

7. The proportion of fans in use $\left(\mathrm{P}_{\mathrm{f}} \%\right)$ increased as the temperature increased, and it reached a maximum of $81 \%$ when the mean indoor temperatures peaked at $28.5{ }^{\circ} \mathrm{C}$. Use of fans elevated the comfort temperature by about $3{ }^{\circ} \mathrm{C}$ in naturally ventilated buildings.

The results from this study indicate that subjects in naturally ventilated buildings are more comfortable at temperature higher than recommended in Indian codes. This study can help architects, building designer and building owners to create comfortable indoor thermal environment. 


\section{Acknowledgement}

This work is supported by Joint clean Energy Research Development Center (JCERDC) for buildings called Center for Building Energy Research and Development (CBERD) funded by the Indian Ministry of Science \& Technology and U.S. Department of Energy and administered by Indo-US Science and Technology Forum in India.

\section{References}

[1] American Society of Heating, Refrigerating and Air-conditioning Engineers Inc.," Thermal environmental conditions for human occupancy," ASHRAE 55-2013.

[2] ISO 7730, "Moderate thermal environment - determination of PMV and PPD indices and specifications of the conditions for thermal comfort," International Organization for Standardization, Geneva, Switzerland, 2005.

[3] Brager G. S. and de Dear R J., "Developing an adaptive model of thermal comfort and preferences," Final Report, ASHRAE RP-884; March 1998.

[4] Humphreys M. A. and Nicol J. F., "Understanding the adaptive approach to thermal comfort," ASHRAE Transaction, vol. 104, pp. 991-1004, 1998.

[5] Yao R., Li B., and Liu J., "A theoretical adaptive model of thermal comfort. Adaptive predicted mean vote (aPMV)," Building and Environment, vol. 44, pp. 2088-2096, 2009.

[6] Nicol J. F., "Adaptive thermal comfort standards in the hot \& humid tropics.," Energy Build, vol. 36, pp. 628-37, 2004.

[7] Auliciems A., "Towards A Psychophysiological Model of Thermal Perception," International Journal for Biometeorology, vol. 25(2), pp. 109-122, 1981

[8] Nicol J. F., Humphreys M. A., and Roaf S., Adaptive Thermal Comfort: Principles and Practice. London, UK: Earthscan, 2012.

[9] Cândido C. , de Dear RJ, and Lamberts R., "Combined thermal acceptability and air movement assessments in a hot humid climate," Building \& Environment, vol. 46(2), pp. 379-85, 2011.

[10] Bureu of Indian Standards (BIS), "National Building Code of India," 2007.

[11] Sharafat A., Sharma M.R., "Tropical summer index - a study of thermal comfort of Indian subjects.," Build Environ, vol. 21(1), pp. 948-60, 1986.

[12] Indraganti M., "Using the adaptive model of thermal comfort for obtaining indoor neutral temperature: Findings from a field study in Hyderabad, India," Build Environment, vol. 45, pp. 519-536, 2010.

[13] Singh M. K., Mahapatra S., and Atreya S. K., "Thermal performance study and evaluation of comfort temperatures in vernacular buildings of North-East India," Building and Environment, vol. 45, pp. 320-329, 2010.

[14] Dhaka S., Mathur J., Brager G.S., Honnekari A. , "Thermal Environmental Conditions and quantifiacation of thermal adaptation in naturally ventilated buildings in ccomposite climate of India.," Building and Environment, vol. 86, pp. 17-28, 2015. 
[15] Manu S., Shukla Y., Rawal R., Thomas L. E., and de Dear R, "Field Studies of Thermal Comfort Across Multiple Climate Zones for the Subcontinent:India Model for Adaptive Comfort (IMAC)," Building and Environment, p. 10.1016/j.buildenv.2015.12.019, 2016.

[16] Nicol J.F., "An analysis of some observations of thermal comfort in Roorkie, India and Baghadad, Iraq.," Ann Hum Biol, vol. 1(4), pp. 411-26, 1974.

[17] Wong N.H., Feriadi H., "Thermal comfort for naturally ventilated house in Indonesia," Energy Build, vol. 36, pp. 614-26, 2004.

[18] Brager G. S., Paliaga G., and de Dear RJ, "Operable windows, personal control," ASHRAE Transaction 110(Part 2):17-35, 2004.

[19] Rijal H. B., Nicol J. F., Humphrey M.A., and Roaf S., "Development of adaptive algorithms for the operation of windows, fans and doors to predict thermal comfort and energy use in Pakistani buildings," ASHRAE Trans., vol. 114, pp. 555-573, 2008.

[20] Indraganti M., "Behavioural adaptation and the use of environmental controls in summer for thermal comfort in apartments in India," Energy and Build, vol. 42, pp. 1019-25, 2010

[21] Rijal H. B., Tuohy P., Humphreys M.A., Nicol J.F., Samuel A., Clarke J.; "Using results from field surveys to predict the effect of open windows on thermal comfort and energy use in buildings," Energy \& Building, vol. 39, pp. 823-836, 2007.

[22] Nicol J. F. and Humphreys M. A., "A stochastic approach to thermal comfort - occupant behaviour and energy use in buildings," ASHRAE Transaction 554-68, 2004.

[23] Dhaka S. , Mathur J., Wagner A., Agarwal G, Garg V., "Evaluation of thermal environmental conditions and thermal perception at naturally ventilated hostels of undergraduate students in composite climate.," Building and Environment, vol. 66(8), pp. 42-53, 2013.

[24] Indraganti M., "Adaptive use of natural ventilation for thermal comfort in Indian apartments," Building and Environment, vol. 45, pp. 1490-1507, 2010.

[25] Bansal N.K., Milne G., Climatic zones and rural housing in India.German -Indian Coorporation in Scientific Research and Technology Development.: ISBN 9783893361625, 1995.

[26] Bureu of Energy Efficiency, "Energy conservation code ," 2007.

[27] Mishra A. K. and Ramgopal M., "Thermal comfort in undergraduate laboratories-A field study in Kharagpur, India," Building and Environment, vol. 71, pp. 223-232, 2014.

[28] Brager G.S., de Dear RJ, Fountain M., "Expectations of indoor climate control," Energy Build, vol. 24, pp. 179-82, 1996.

[29] Givoni B., "Comfort, climate analysis and building design guidelines ," Energy and Build, vol. 18, pp. 11-23, 1992.

[30] Nicol J. F., "Adaptive thermal comfort standards in the hot \&humid tropics.," Energy Build, vol. 36, pp. 628-37, 2004.

[31] Arens E., Humphreys M. A., de Dear RJ., and Zhang H. , "Air movement preferences observed in office buildings.," Int J Biometeorol, vol. 51, pp. 349-60, 2007 
[32] Nicol J. F. and Roaf S., "Pioneering new indoor temperature standards: the Pakistan project.," Energy and Building, vol. 23, pp. 169-74, 1996.

[33] Karyono, T. H., "Report on thermal comfort and building energy studies in Jakarta, Indonesia," Building and Environment, vol. 35, pp. 77-90, 2000.

[34] Zhang Y., Jinyong W. , Huimei C. , Zhang J. , and Meng Q. , "Thermal comfort in naturally ventilated buildings in hot-humid area of China," Building and Environment, vol. 45, pp. 25622570,2010

[35] Humphreys M. A., Nicol J.F., "Maximum temperature in European office buildings to avoid heat discomfort.," Solar Energy, vol. 81(3), pp. 295-304, 2007.

[36] Rijal H. B., Yoshida H., and Umemiya N., "Seasonal and regional differences in neutral temperatures in Nepalese traditional vernacular houses," Building and Environment, vol. 45, pp. 2743-2753, 2010.

[37] Rijal H. B., Nicol J. F., and Humphrey M. A., "Updating the adaptive relation between climate and comfort indoors; new insights and an extended database," Building and Environment, vol. 63, pp. 40-55, 2013.

[38] de Dear RJ and Leow K.G., "Thermal comfort in the humid tropics: field experiments in air conditioned and naturally ventilated buildings in Singapore," International Journal of Biometeorlgy, vol. 34, pp. 259-65, 1991.

[39] Singh M. K., Mahapatra S., Teller J., "Development of thermal comfort models for various climatic zones of North-East India," Sustainable cities and Society, vol 14, pp 133-145, 2015.

[40] Singh M. K., Mahapatra S., Atreya S.K., "Adaptive thermal comfort model for different climatic zones of North-East India," Applied Energy, vol. 88, pp. 2420-2428, 2011.

[41] Mui K.W. H. and Chan W.T.D., "Adaptive comfort temperature model of airconditioned buildings in Hong Kong," Building and Environment, vol. 38, pp. 837-852, 2003..

[42] Indraganti M., Ooka R., Rijal H. B., and Brager G. S., "Adaptive model of thermal comfort for offices in hot and humid climates of India.," Building and Environment, vol. 74, pp. 39-53, 2014. 


\section{List of Tables}

Table 1 Buildings and subjects surveyed details

Table 2 Details of Instruments used in field study for environmental measurements

Table 3 Summary of subject's details

Table 4 Descriptive Indoor and outdoor environmental parameters observed

Table 5 Descriptive statistics of subjective thermal sensation and preference variables

Table 6 Linear regression models, Griffiths' comfort temperature $\left(\mathrm{GC}=0.5 \mathrm{~K}^{-1}\right)$, Globe temperature when voting neutral $\left(\mathrm{T}_{\mathrm{gn}}\right)$

Table 7 Comfort temperature predicted by Griffith method

Table 8 Deciles of mean globe temperature, outdoor air temperature and the proportion of windows open in naturally ventilated buildings

Table 9 Correlation matrix for proportion of window open with outdoor \& indoor environmental parameters 
Table 1 Buildings and subjects surveyed details

\begin{tabular}{|c|c|c|c|c|c|c|}
\hline \multicolumn{4}{|l|}{ Building details } & \multicolumn{3}{|c|}{ Subject's details } \\
\hline Building Title & Type(Office/Residential) & Age of buildings (years) & Ownership & Sample size & Male sample & Female Samples \\
\hline 01 & Office & 40 & Govt. & 175 & 140 & 35 \\
\hline $\mathbf{O 2}$ & Office & 8 & Govt. & 95 & 57 & 38 \\
\hline $\mathbf{O 3}$ & Office & 25 & Govt. & 12 & 7 & 5 \\
\hline 04 & Office & 40 & Private & 25 & 20 & 5 \\
\hline O5 & Office & 10 & Govt. & 98 & 85 & 13 \\
\hline 06 & Office & 15 & Private & 5 & 2 & 3 \\
\hline O7 & Office & 15 & Private & 12 & 9 & 3 \\
\hline 08 & Office & 10 & Private & 8 & 7 & 1 \\
\hline 09 & Office & 10 & Private & 12 & 10 & 2 \\
\hline 010 & Office & 40 & Govt. & 24 & 24 & 0 \\
\hline 011 & Office & 10 & Private & 7 & 3 & 4 \\
\hline 012 & Office & 30 & Govt. & 38 & 33 & 5 \\
\hline 013 & Office & 10 & Private & 36 & 24 & 12 \\
\hline 014 & Office & 30 & Govt. & 64 & 54 & 10 \\
\hline R16 & Residential & 40 & Govt. & 248 & 248 & - \\
\hline R17 & Residential & 40 & Govt. & 33 & 33 & - \\
\hline R18 & Residential & 40 & Govt. & 55 & - & 55 \\
\hline R19 & Residential & 30 & Govt. & 5 & 5 & - \\
\hline R20 & Residential & 30 & Govt. & 228 & 228 & - \\
\hline R21 & Residential & 40 & Govt. & 228 & 228 & - \\
\hline R22 & Residential & 40 & Govt. & 108 & 108 & - \\
\hline R23 & Residential & 40 & Govt. & 206 & 206 & - \\
\hline R24 & Residential & 25 & Govt. & 18 & 12 & 6 \\
\hline R25 & Residential & 10 & Govt. & 335 & & 335 \\
\hline R26 & Residential & 40 & Govt. & 38 & 38 & - \\
\hline R27 & Residential & 40 & Govt. & 70 & 60 & - \\
\hline R28 & Residential & 30 & Govt. & 249 & 240 & 9 \\
\hline R29 & Residential & 40 & Govt. & 32 & 32 & - \\
\hline R30 & Residential & 10 & Private & 38 & 30 & 8 \\
\hline R31 & Residential & 10 & Private & 73 & 50 & 23 \\
\hline R32 & Residential & 10 & Private & 35 & 10 & 25 \\
\hline All & 32 & & & 2610 & 2013 & 597 \\
\hline
\end{tabular}


Table 2 Details of Instruments used in field study for environmental measurements

\begin{tabular}{llllll}
\hline S. No. & Parameter & Instrument & Make & Range & Accuracy \\
\hline 1 & Outdoor temperature & Weather station (MNIT, Jaipur) & Virtual instrumentation & $-40-123.8^{\circ} \mathrm{C}$ & $\pm 0.5^{\circ} \mathrm{C}\left(5-40^{\circ} \mathrm{C}\right)$ \\
\hline 2 & Indoor air temperature & $480 \mathrm{VAC}$ & Testo & $-20-70{ }^{\circ} \mathrm{C}$ & $\pm 0.5^{\circ} \mathrm{C}$ \\
\hline 3 & Globe temperature & $480 \mathrm{VAC}$ & Testo & $0-120^{\circ} \mathrm{C}$ & $\pm 0.5^{\circ} \mathrm{C}$ \\
\hline 4 & Relative humidity & $480 \mathrm{VAC}$ & Testo & $0-100 \% \mathrm{RH}$ & $\pm(1.0 \% \mathrm{RH}+0.7 \% \mathrm{reading})$ \\
\hline 5 & Air velocity & $480 \mathrm{VAC}$ & Testo & $0-5 \mathrm{~m} / \mathrm{s}$ & $\pm(0.03 \mathrm{~m} / \mathrm{s}+4 \mathrm{reading})$ \\
\hline 6 & $\mathrm{CO}_{2}$ & $435-2$ & Testo & $0-10000 \mathrm{ppm}$ & $\pm\left(50 \mathrm{ppm} \mathrm{CO} \mathrm{C}_{2}+2 \%\right.$ of reading $)$ \\
\hline 7 & Lighting level & LX-103 & Lutron & $0-50000$ lux & $\pm 4 \%$ of $10 \mathrm{digit}$ \\
\hline
\end{tabular}


Table 3 Summary of subject's details

\begin{tabular}{|c|c|c|c|c|c|c|c|c|c|c|c|c|c|c|c|c|}
\hline \multirow[t]{4}{*}{ Variable } & \multicolumn{16}{|c|}{ Seasons } \\
\hline & \multicolumn{4}{|c|}{ Summer } & \multicolumn{4}{|c|}{ Moderate } & \multicolumn{4}{|c|}{ Winter } & \multicolumn{4}{|c|}{ All seasons } \\
\hline & \multicolumn{2}{|c|}{ Male } & \multicolumn{2}{|c|}{ Female } & \multicolumn{2}{|c|}{ Male } & \multicolumn{2}{|c|}{ Female } & \multicolumn{2}{|c|}{ Male } & \multicolumn{2}{|c|}{ Female } & \multicolumn{2}{|c|}{ Male } & \multicolumn{2}{|c|}{ Female } \\
\hline & M & SD & $M$ & $\mathrm{SD}$ & M & $\mathrm{SD}$ & M & SD & M & $\mathrm{SD}$ & M & SD & $\mathrm{M}$ & SD & M & $\mathrm{SD}$ \\
\hline Sample size & \multicolumn{2}{|c|}{882} & \multicolumn{2}{|c|}{312} & \multicolumn{2}{|c|}{270} & \multicolumn{2}{|c|}{166} & \multicolumn{2}{|c|}{270} & \multicolumn{2}{|c|}{166} & \multicolumn{2}{|c|}{2013} & \multicolumn{2}{|c|}{597} \\
\hline Age & 27 & 10.4 & 22 & 6.8 & 22 & 6.2 & 21 & 3.6 & 24 & 5.1 & 20 & 2.1 & 25 & 7.8 & 21 & 4.8 \\
\hline Weight(kg) & 65.9 & 11.30 & 52.1 & 7.16 & 64.4 & 10.02 & 51.9 & 7.09 & 64.0 & 11.63 & 50.7 & 7.18 & 63.8 & 9.83 & 51.4 & 7.12 \\
\hline BSA & 1.75 & 0.16 & 1.53 & 0.13 & 1.73 & 0.18 & 1.51 & 0.11 & 1.76 & 0.18 & 1.49 & 0.14 & 1.75 & 0.17 & 1.50 & 0.13 \\
\hline $\mathbf{I}_{\mathrm{c}, \mathrm{tot}}(\mathbf{c l o})$ & 0.31 & 0.08 & 0.42 & 0.09 & 0.34 & 0.07 & 0.43 & 0.08 & 0.67 & 0.22 & 0.65 & 0.20 & 0.41 & 0.19 & 0.46 & 0.19 \\
\hline $\begin{array}{l}\text { Activity } \\
\text { (Met) }\end{array}$ & 1.08 & 0.15 & 1.1 & 0.11 & 1.07 & 0.17 & 1.03 & 0.11 & 1.04 & 0.10 & 1.01 & 0.07 & 1.06 & 0.14 & 1.06 & 0.11 \\
\hline
\end{tabular}

M: Mean of sample; SD: standard deviation of sample size; BSA: Body surface area. 
Table 4 Descriptive indoor and outdoor environmental parameters observed

\begin{tabular}{|c|c|c|c|c|c|c|c|c|}
\hline \multirow[t]{3}{*}{ Parameters } & \multicolumn{8}{|c|}{ Seasons } \\
\hline & \multicolumn{2}{|c|}{ Summer } & \multicolumn{2}{|c|}{ Moderate } & \multicolumn{2}{|c|}{ Winter } & \multicolumn{2}{|c|}{ All seasons } \\
\hline & Mean & SD & Mean & SD & Mean & SD & Mean & SD \\
\hline Sample size & \multicolumn{2}{|c|}{1220} & \multicolumn{2}{|c|}{438} & \multicolumn{2}{|c|}{952} & \multicolumn{2}{|c|}{2610} \\
\hline $\mathbf{T}_{\mathrm{mm}}\left({ }^{\circ} \mathbf{C}\right)$ & 30.2 & 3.44 & 25.6 & 3.02 & 17.5 & 2.87 & 25.0 & 6.66 \\
\hline $\mathbf{T}_{\mathbf{o}}\left({ }^{\circ} \mathrm{C}\right)$ & 34.0 & 3.39 & 31.3 & 2.77 & 22.8 & 4.38 & 29.4 & 6.56 \\
\hline $\mathbf{T}_{\mathrm{a}}\left({ }^{\circ} \mathbf{C}\right)$ & 31.7 & 2.87 & 29.1 & 2.97 & 21.9 & 3.62 & 27.7 & 5.49 \\
\hline $\mathbf{T}_{\mathrm{op}}\left({ }^{\circ} \mathrm{C}\right)$ & 31.8 & 2.86 & 29.2 & 2.89 & 22.1 & 3.60 & 27.8 & 5.42 \\
\hline $\mathbf{T}_{\mathrm{g}}\left({ }^{\circ} \mathrm{C}\right)$ & 31.9 & 2.87 & 29.3 & 2.84 & 22.4 & 3.60 & 28.0 & 5.37 \\
\hline RH (\%) & 46 & 20.1 & 32 & 12.2 & 43 & 13.8 & 43 & 17.8 \\
\hline $\mathrm{Va}(\mathrm{m} / \mathrm{s})$ & 0.62 & 0.39 & 0.57 & 0.37 & 0.27 & 0.19 & 0.60 & 0.43 \\
\hline $\mathrm{CO}_{2}$ & 545 & 242 & 537 & 129 & 582 & 137 & 582 & 305 \\
\hline $\mathbf{I}_{\mathrm{cl}, \text { tot }}(\mathbf{c l o})$ & 0.34 & 0.15 & 0.34 & 0.06 & 0.67 & 0.14 & 0.42 & 0.15 \\
\hline Activity(Met) & 1.08 & 0.13 & 1.06 & 0.14 & 1.04 & 0.10 & 1.06 & 0.12 \\
\hline
\end{tabular}

$T_{m m}$ : Outdoor monthly mean temperature $\left({ }^{\circ} \mathrm{C}\right) ; T_{o}$ :Outdoor temperature $\left({ }^{\circ} \mathrm{C}\right) ; T_{a}:$ Indoor air temperature $\left({ }^{\circ} \mathrm{C}\right) ; T_{\text {op }}:$ Indoor operative temperature; $T_{g}$ :Indoor globe temperature $\left({ }^{\circ} \mathrm{C}\right) ; \mathrm{RH}$ : Indoor relative humidity; $V_{a}:$ Indoor air velocity $(\mathrm{m} / \mathrm{s}) ; \mathrm{CO}_{2}:$ Indoor $\mathrm{CO}_{2}$ concentration(ppm); $I_{c l, t o t}$ :Total clothing insulation(clo); Met: Metabolic activities. 
Table 5 Descriptive statistics of subjective thermal sensation and preference variables

\begin{tabular}{|c|c|c|c|c|c|c|c|c|}
\hline \multirow[t]{3}{*}{ Variables } & \multicolumn{8}{|c|}{ Seasons } \\
\hline & \multicolumn{2}{|c|}{ Summer } & \multicolumn{2}{|c|}{ Moderate } & \multicolumn{2}{|c|}{ Winter } & \multicolumn{2}{|c|}{ All seasons } \\
\hline & Mean & SD & Mean & SD & Mean & SD & Mean & SD \\
\hline Sample size & \multicolumn{2}{|c|}{1220} & \multicolumn{2}{|c|}{438} & \multicolumn{2}{|c|}{952} & \multicolumn{2}{|c|}{2610} \\
\hline TSV & 0.67 & 0.92 & 0.56 & 0.92 & -0.75 & 0.76 & 0.16 & 1.24 \\
\hline TPV & -0.84 & 0.66 & -0.51 & 0.78 & 0.37 & 0.80 & -0.22 & 0.92 \\
\hline HSV & +0.21 & 1.26 & -0.23 & 0.87 & -0.35 & 0.82 & 0.13 & 1.09 \\
\hline HPV & -0.17 & 1.01 & 0.00 & 0.68 & +0.10 & 0.66 & 0.00 & 0.85 \\
\hline AVS & -0.35 & 1.09 & -0.25 & 1.01 & -0.10 & 0.62 & -0.10 & 0.97 \\
\hline APV & 0.67 & 0.72 & 0.61 & 0.71 & 0.20 & 0.65 & 0.49 & 0.72 \\
\hline PMV & 1.73 & 1.48 & 0.22 & 1.40 & -1.90 & 1.18 & 0.14 & 2.15 \\
\hline PPD (\%) & 56.03 & 35.48 & 35.65 & 30.40 & 66.48 & 33.98 & 56.07 & 35.59 \\
\hline
\end{tabular}

TSV: Thermal Sensation Vote; TPV: Thermal Preference Vote; HSV: Humidity Sensation Vote; HPV: Humidity Preference Vote; AVS: Air Velocity Sensation Vote; AVP: Air velocity Preference Vote; PMV: Predicated Mean Vote; PPD: Predicted Percentage Dissatisfied. 
Table 6 Linear regression models, Griffiths' comfort temperature $\left(\mathrm{GC}=0.5 \mathrm{~K}^{-1}\right)$, globe temperature when voting neutral $\left(\mathrm{T}_{\mathrm{gn}}\right)$

\begin{tabular}{|c|c|c|c|c|c|c|c|}
\hline Case & $\mathbf{N}$ & Regression Models ${ }^{\text {a }}$ & $\mathbf{R}^{2}$ & $\mathbf{T}_{\mathrm{n}}\left({ }^{\circ} \mathrm{C}\right)$ & Mean $\mathbf{T}_{\mathbf{g n}}$ & $\mathbf{N}_{\mathbf{n}}$ & $\begin{array}{l}\text { Mean } T_{c}\left({ }^{\circ} \mathrm{C}\right) \\
\left(G C=0.5^{\circ} C^{-1}\right)\end{array}$ \\
\hline \multirow{3}{*}{ All Season data } & \multirow{3}{*}{2610} & $\mathrm{TS}=0.149 \mathrm{~T}_{\mathrm{g}}-4.06$ & 0.55 & 27.2 & 28.1 & 1040 & 27.9 \\
\hline & & $\mathrm{TS}=0.148 \mathrm{~T}_{\mathrm{a}}-3.98$ & 0.56 & 26.9 & 28.1 & & \\
\hline & & $\mathrm{TS}=0.149 \mathrm{~T}_{\mathrm{op}}-4.05$ & 0.56 & 27.2 & 28.4 & & \\
\hline \multirow{3}{*}{ Summer season } & \multirow{3}{*}{1220} & $\mathrm{TS}=0.182 \mathrm{~T}_{\mathrm{g}}-4.99$ & 0.31 & 27.4 & 30.5 & 504 & 30.6 \\
\hline & & $\mathrm{TS}=0.181 \mathrm{~T}_{\mathrm{a}}-4.98$ & 0.31 & 27.5 & 30.4 & & \\
\hline & & $\mathrm{TS}=0.180 \mathrm{~T}_{\mathrm{op}}-5.04$ & 0.31 & 28.0 & 30.5 & & \\
\hline \multirow{3}{*}{ Moderate season } & \multirow{3}{*}{438} & $\mathrm{TS}=0.177 \mathrm{~T}_{\mathrm{g}}-5.04$ & 0.42 & 28.5 & 29.5 & 202 & 29.5 \\
\hline & & $\mathrm{TS}=0.184 \mathrm{~T}_{\mathrm{a}}-5.19$ & 0.43 & 28.2 & 29.1 & & \\
\hline & & $\mathrm{TS}=0.186 \mathrm{~T}_{\mathrm{op}}-5.28$ & 0.44 & 28.4 & 29.3 & & \\
\hline \multirow{3}{*}{ Winter season } & \multirow{3}{*}{952} & $\mathrm{TS}=0.101 \mathrm{~T}_{\mathrm{g}}-2.99$ & 0.28 & 29.6 & 24.6 & 334 & 25.2 \\
\hline & & $\mathrm{TS}=0.113 \mathrm{~T}_{\mathrm{a}}-3.18$ & 0.29 & 28.1 & 24.2 & & \\
\hline & & $\mathrm{TS}=0.109 \mathrm{~T}_{\mathrm{op}}-3.14$ & 0.29 & 28.8 & 24.9 & & \\
\hline
\end{tabular}

$N=$ Sample size; $T S=$ Thermal sensation vote; $T_{g}=$ Indoor globe temperature; $T_{a}=$ Indoor air temperature; $T_{o p}=$ Indoor operative temperature; $T_{n}=$ Regression neutral temperature; $T_{g n}=$ Indoor globe temperature when voting neutral; $N_{n}=$ Sample size (voting 'neutral' on the sensation scale); $T_{c}=$ Griffiths' comfort temperature $\left({ }^{\circ} \mathrm{C}\right)$ with 0.50 as coefficient.

${ }^{a}$ The regression models are all significant at $(p<0.001)$. 
Table 7 Comfort temperature predicted by Griffith method

\begin{tabular}{|c|c|c|c|c|c|c|c|}
\hline \multirow[b]{2}{*}{ Mode } & \multirow[b]{2}{*}{ GC $\left({ }^{\circ} \mathbf{C}^{-1}\right)$} & \multicolumn{3}{|c|}{$\mathrm{T}_{\mathrm{C}}\left({ }^{\circ} \mathrm{C}\right)$ (Indoor air temperature) } & \multicolumn{3}{|c|}{$\mathrm{T}_{\mathrm{C}}\left({ }^{\circ} \mathrm{C}\right)$ (Globe temperature) } \\
\hline & & $\mathbf{N}$ & Mean & S.D. & $\mathbf{N}$ & Mean & S.D. \\
\hline \multirow{4}{*}{ Naturally ventilated mode } & 0.25 & 2610 & 27.2 & 3.8 & 2610 & 27.6 & 3.6 \\
\hline & 0.33 & 2610 & 27.3 & 3.5 & 2610 & 27.7 & 3.4 \\
\hline & 0.50 & 2610 & 27.4 & 3.2 & 2610 & 27.9 & 3.1 \\
\hline & Voting Neutral & 1040 & 28.1 & 1.6 & 1040 & 28.1 & 1.5 \\
\hline
\end{tabular}


Table 8 Deciles of mean globe temperature, outdoor air temperature and the proportion of windows open in naturally ventilated buildings

\begin{tabular}{|c|c|c|c|c|c|c|c|c|c|c|c|c|c|c|}
\hline \multicolumn{4}{|c|}{ Deciles } & \multicolumn{11}{|c|}{$\mathbf{T}_{\text {out }}\left({ }^{\circ} \mathbf{C}\right)$} \\
\hline & $\mathbf{N}$ & Max. & Min. & Mean & SD & Mean* & SD* & $\mathbf{N}$ & Max. & Min. & Mean & SD & Mean* & SD* $^{*}$ \\
\hline 1 & 266 & 20.5 & 14.5 & 18.1 & 1.54 & 0.26 & 0.44 & 255 & 19.9 & 11.0 & 17.12 & 2.10 & 0.24 & 0.43 \\
\hline 2 & 271 & 22.4 & 20.6 & 21.6 & 0.55 & 0.23 & 0.42 & 270 & 24.0 & 20.0 & 21.80 & 1.29 & 0.20 & 0.40 \\
\hline 3 & 255 & 25.3 & 22.5 & 23.7 & 0.92 & 0.25 & 0.43 & 260 & 26.8 & 24.0 & 25.24 & 0.78 & 0.32 & 0.47 \\
\hline 4 & 261 & 27.8 & 25.4 & 26.7 & 0.79 & 0.39 & 0.49 & 260 & 29.9 & 26.8 & 28.47 & 0.89 & 0.54 & 0.50 \\
\hline 5 & 265 & 29.2 & 27.9 & 28.5 & 0.41 & 0.51 & 0.50 & 260 & 31.0 & 29.9 & 30.41 & 0.35 & 0.56 & 0.50 \\
\hline 6 & 250 & 30.4 & 29.2 & 29.9 & 0.33 & 0.45 & 0.50 & 265 & 32.3 & 31.0 & 31.75 & 0.39 & 0.54 & 0.50 \\
\hline 7 & 260 & 31.5 & 30.4 & 30.9 & 0.31 & 0.64 & 0.48 & 255 & 33.5 & 32.3 & 32.88 & 0.34 & 0.56 & 0.50 \\
\hline 8 & 260 & 32.7 & 31.5 & 32.2 & 0.38 & 0.69 & 0.46 & 260 & 35.1 & 33.5 & 34.18 & 0.45 & 0.60 & 0.49 \\
\hline 9 & 260 & 34.6 & 32.7 & 33.5 & 0.53 & 0.75 & 0.43 & 262 & 37.2 & 35.1 & 36.05 & 0.61 & 0.63 & 0.48 \\
\hline 10 & 260 & 39.6 & 34.6 & 36.3 & 1.28 & 0.51 & 0.50 & 262 & 45.1 & 37.2 & 39.21 & 1.34 & 0.50 & 0.50 \\
\hline
\end{tabular}


Table 9 Correlation matrix for proportion of window open with outdoor \& indoor environmental parameters

\begin{tabular}{|c|c|c|c|c|c|c|c|}
\hline & $\begin{array}{l}\text { Pearson } \\
\text { Correlation } \\
\text { Sig. (2-tailed) }\end{array}$ & $\begin{array}{l}\text { Windows } \\
\text { open }\left(\mathbf{P}_{w} \%\right)\end{array}$ & $\begin{array}{l}\text { Thermal } \\
\text { sensation } \\
\text { vote(TSV) }\end{array}$ & $\begin{array}{l}\text { Outdoor air } \\
\text { temperature } \\
\left(T_{0}\right)\end{array}$ & $\begin{array}{l}\text { Indoor air } \\
\text { temperature } \\
\left(T_{i}\right)\end{array}$ & $\begin{array}{l}\text { Indoor globe } \\
\text { temperature } \\
\left(T_{g}\right) \\
\end{array}$ & $\begin{array}{l}\text { Indoor air } \\
\text { velocity } \\
\left(V_{a}\right) \\
\end{array}$ \\
\hline $\begin{array}{l}\text { Windows open }\left(P_{w}\right. \\
\%)\end{array}$ & $r=$ & 1.00 & $0.16^{* *}$ & $0.24 * *$ & $0.30 * *$ & $0.29 * *$ & $0.08 * *$ \\
\hline $\begin{array}{l}\text { Thermal sensation } \\
\text { vote(TSV) }\end{array}$ & $r=$ & $0.16^{* *}$ & 1.00 & $0.56^{* *}$ & $0.60 * *$ & $0.60 * *$ & $0.10^{* *}$ \\
\hline $\begin{array}{l}\text { Outdoor air } \\
\text { temperature }\left(T_{0}\right)\end{array}$ & $r=$ & $0.24^{* *}$ & $0.56^{* *}$ & 1.00 & $0.88^{* *}$ & $0.87 * *$ & $0.12^{* *}$ \\
\hline $\begin{array}{l}\text { Indoor air } \\
\text { temperature }\left(T_{i}\right)\end{array}$ & $r=$ & $0.30^{* *}$ & $0.60^{* *}$ & $0.88 * *$ & 1.00 & $0.98 * *$ & $0.15^{* *}$ \\
\hline $\begin{array}{l}\text { Indoor globe } \\
\text { temperature }\left(T_{g}\right)\end{array}$ & $r=$ & $0.29 * *$ & $0.60 * *$ & $0.87 * *$ & $0.98 * *$ & 1.00 & $0.16^{* *}$ \\
\hline $\begin{array}{l}\text { Indoor air } \\
\text { velocity }\left(V_{a}\right)\end{array}$ & $r=$ & $0.08^{* *}$ & $0.10^{* *}$ & $0.12^{* *}$ & $0.15^{* *}$ & $0.16^{* *}$ & 1.00 \\
\hline
\end{tabular}




\section{$\underline{\text { List of Figures }}$}

Figure1 Methodology of the study

Figure 2 Details of daily mean outdoor and indoor environmental parameters observed during field study.

Figure 3 Distribution of thermal sensation responses in different seasons for field study.

Figure 4 Cross tabulated summary of thermal preference votes and thermal sensation votes

Figure 5 Cross tabulated summary of humidity preference votes and humidity sensation votes

Figure 6 Distribution of air velocity sensation votes over air velocity through boxplots

Figure 7 Distribution of the preference votes across air velocity over operative temperature (binned to $2{ }^{\circ} \mathrm{C}$ ).

Figure 8 Linear regression of thermal sensation with indoor operative temperature(with $95 \% \mathrm{CI}$ )

Figure 9 Seasonal variation of comfort temperature (Griffith constant $0.5^{\circ} \mathrm{C}^{-1)}$ for naturally ventilated buildings (at 95\% CI)

Figure 10a Variation of clothing with instantaneous outdoor temperature for winter

Figure 10b Variation of clothing with instantaneous outdoor temperature for moderate

Figure 10c Variation of clothing with instantaneous outdoor temperature for summer season

Figure11 Proportion of controls in use and prevailing indoor mean air velocity for all seasons in naturally conditioned building

Figure12 Deciles of mean globe temperature (a) and mean outdoor temperature (b) with the proportion of 'windows open' in naturally ventilated buildings

Figure 13 Deciles of mean globe temperature and the proportion of 'fans on' in naturally ventilated buildings 


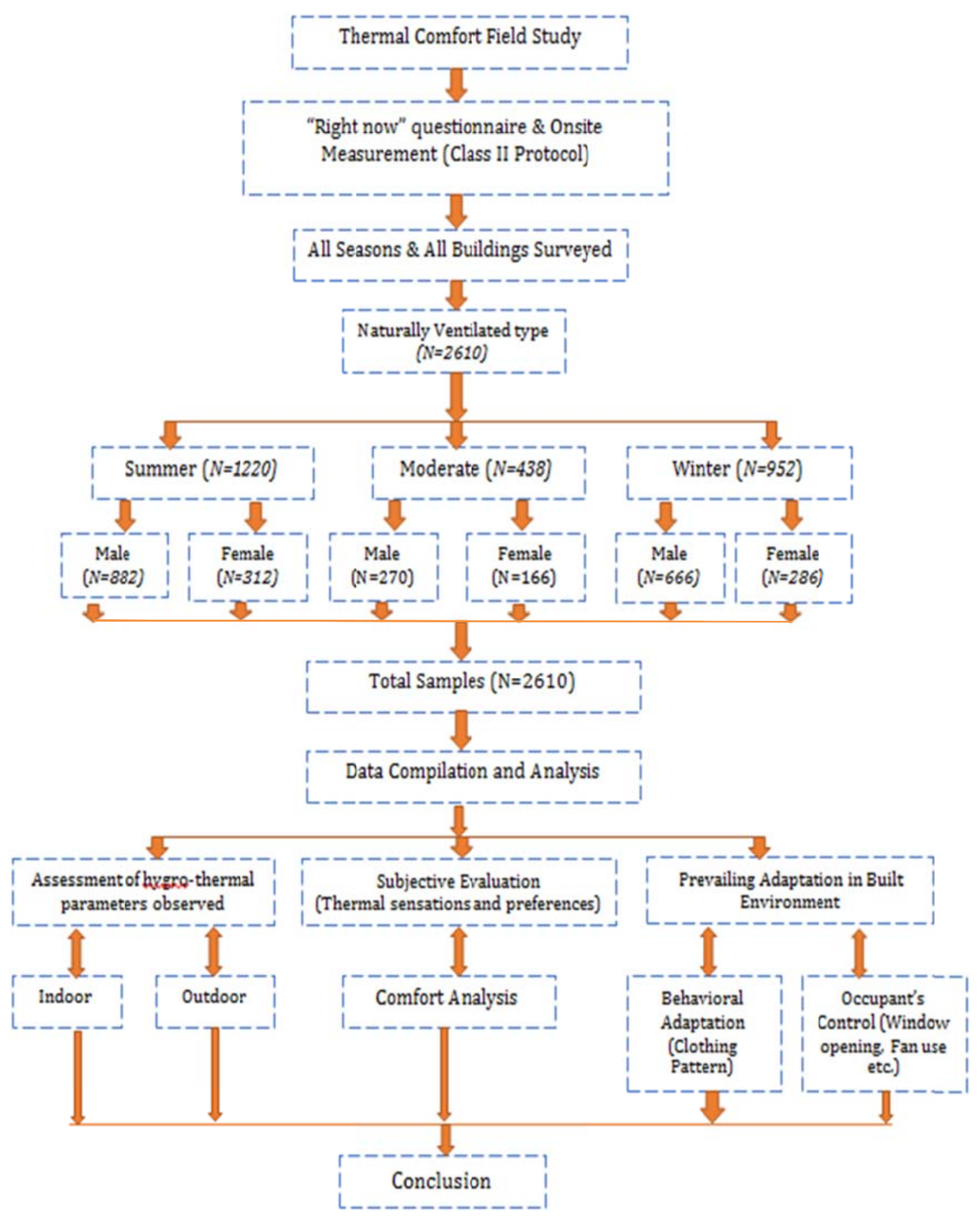

Figure 1 Methodology of the study 


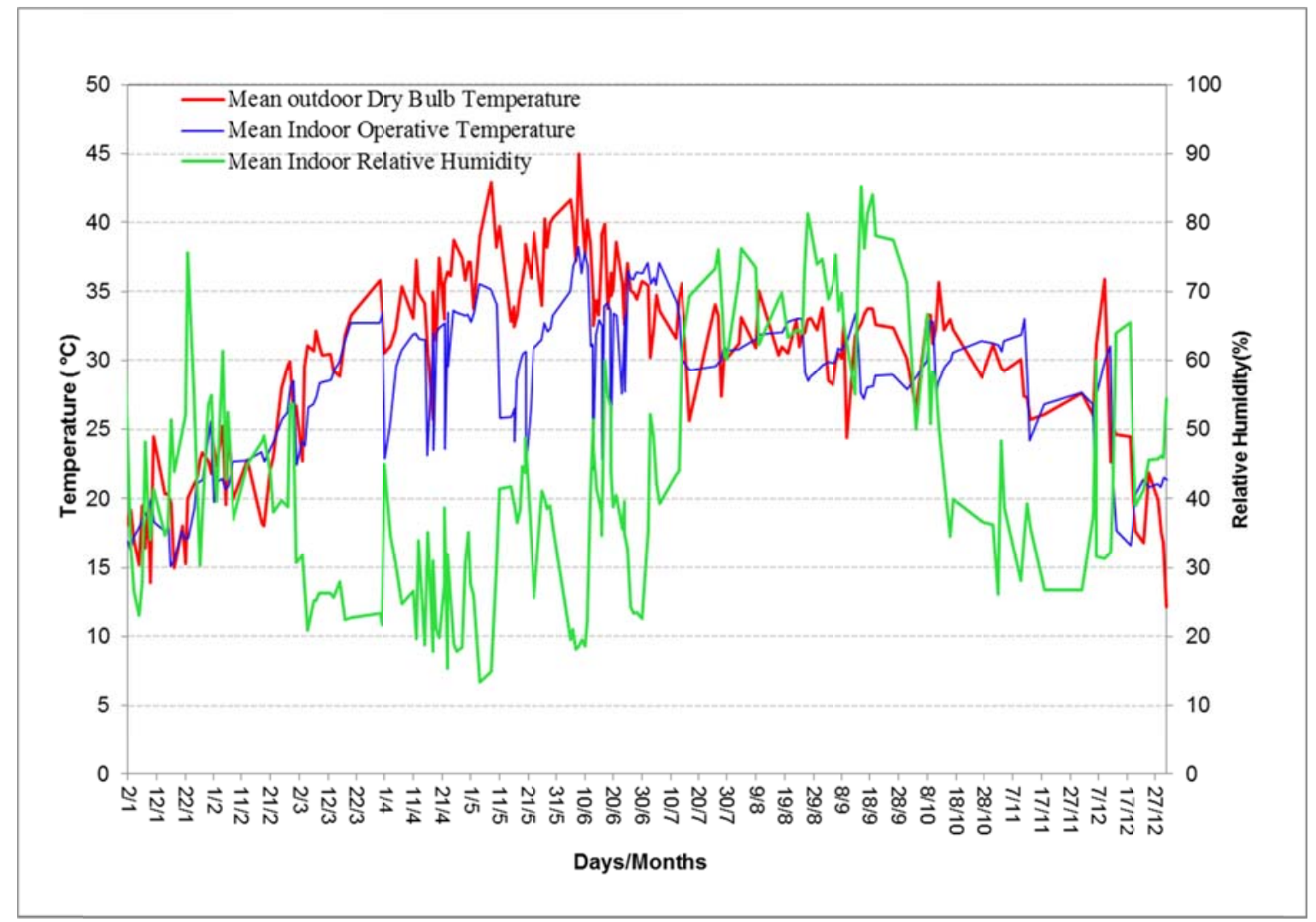

Figure 2 Details of daily mean outdoor and indoor environmental parameters observed during field study 


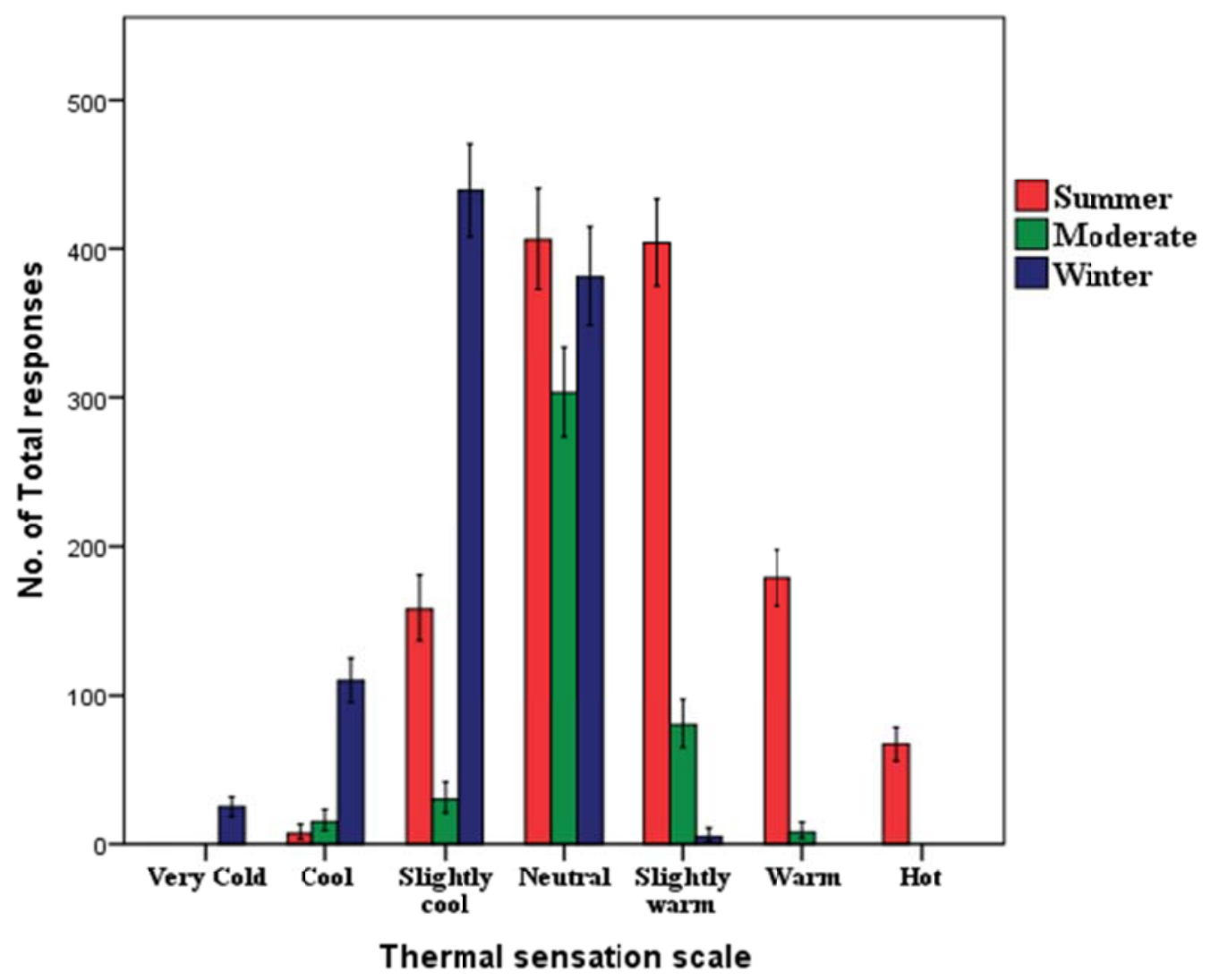

Error Bars: $95 \% \mathrm{Cl}$

Figure 3 Distribution of thermal sensation responses in different seasons for fields study. 


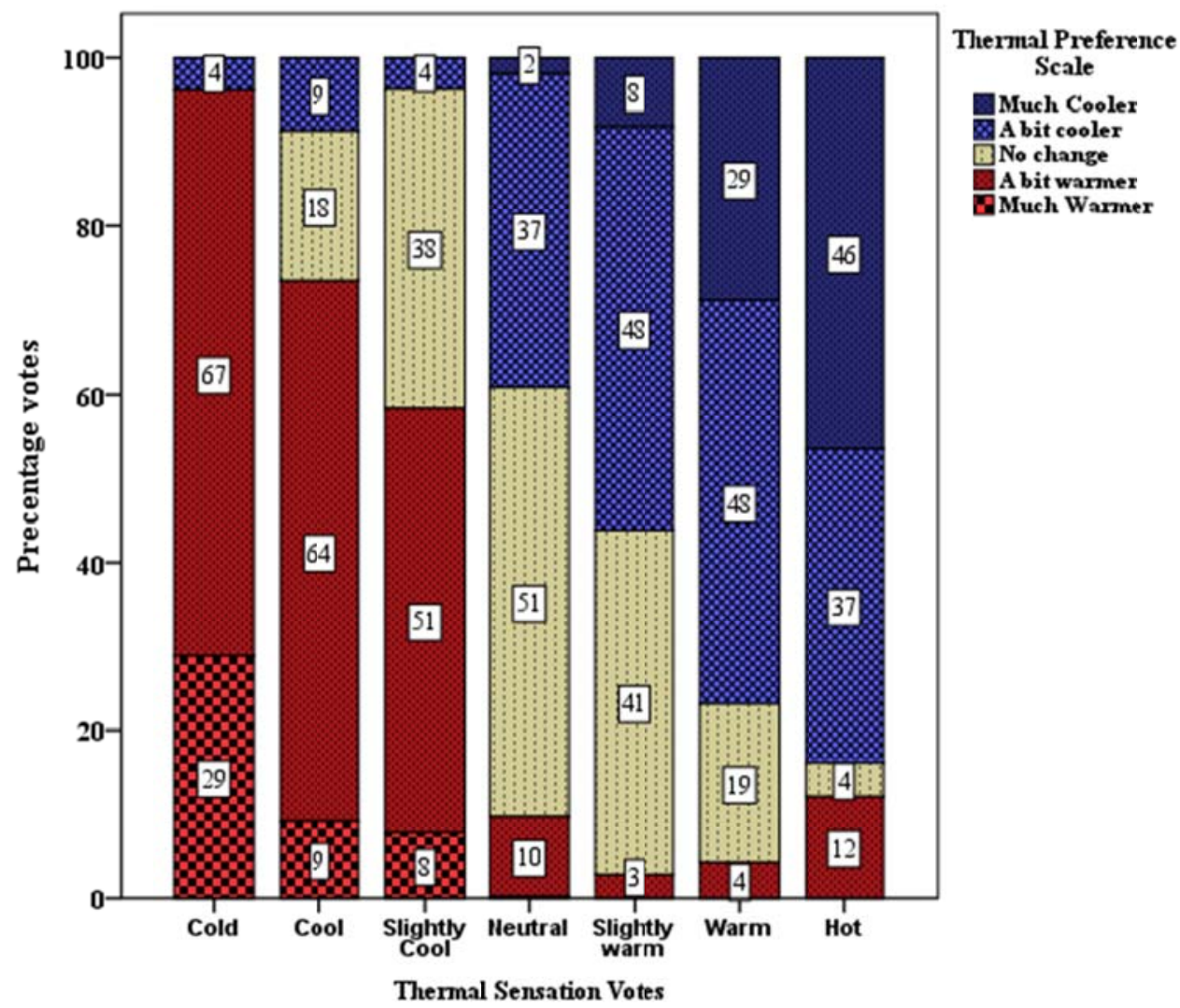

Figure 4 Cross tabulated summary of thermal preference votes and thermal sensation votes 


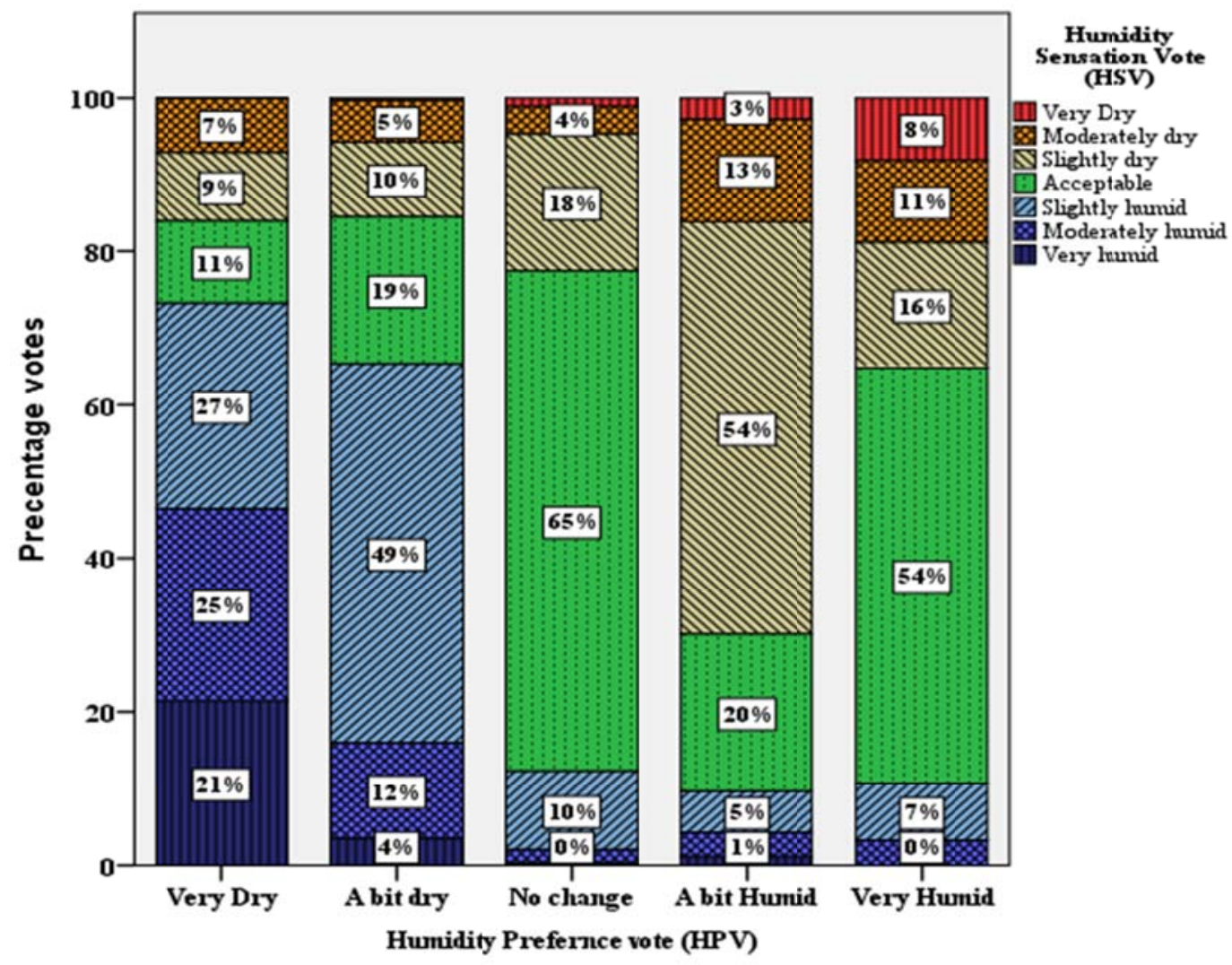

Figure 5 Cross tabulated summary of humidity preference votes and humidity sensation votes. 


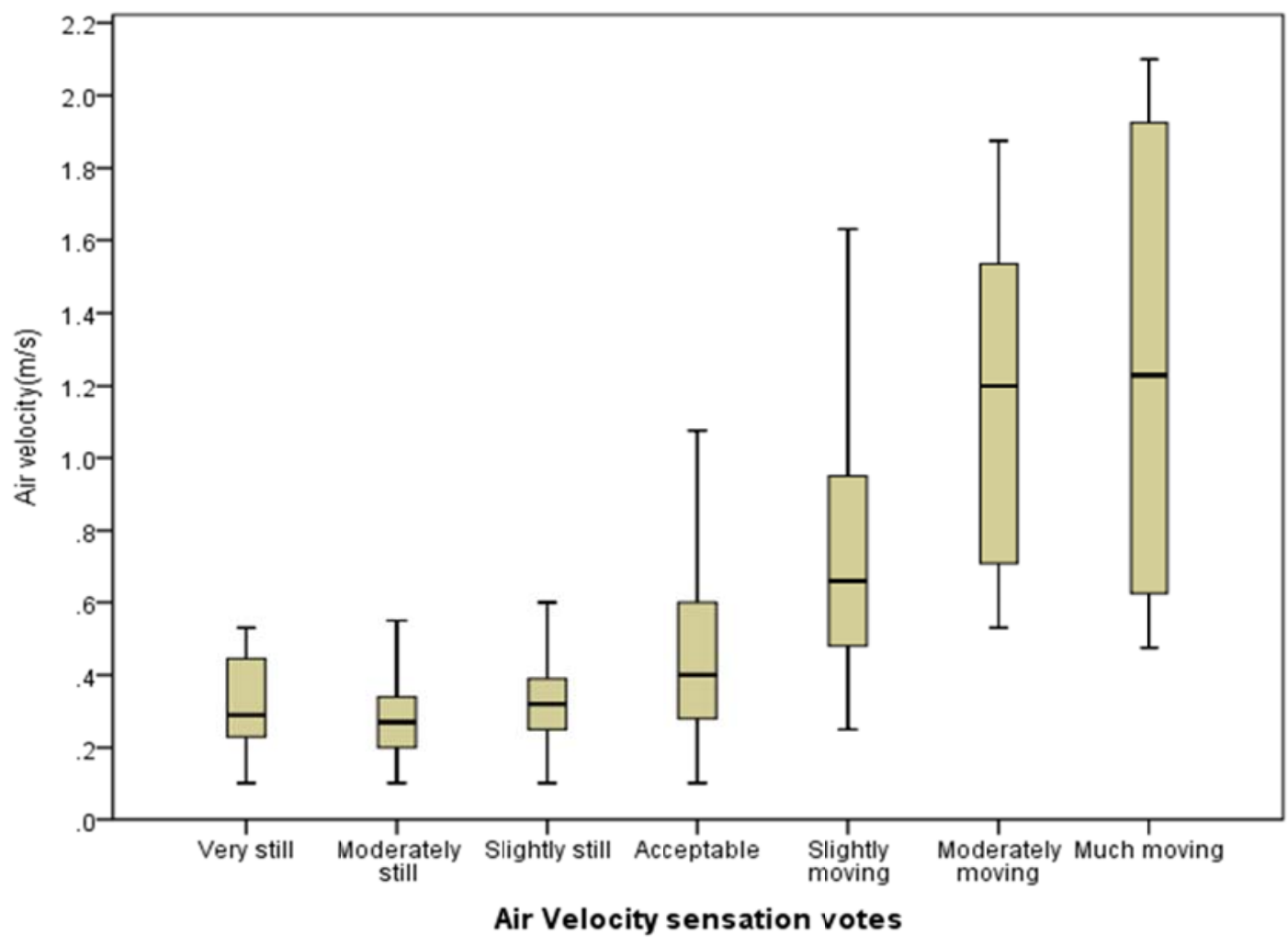

Figure 6 Distribution of air velocity sensation votes over air velocity through boxplots 


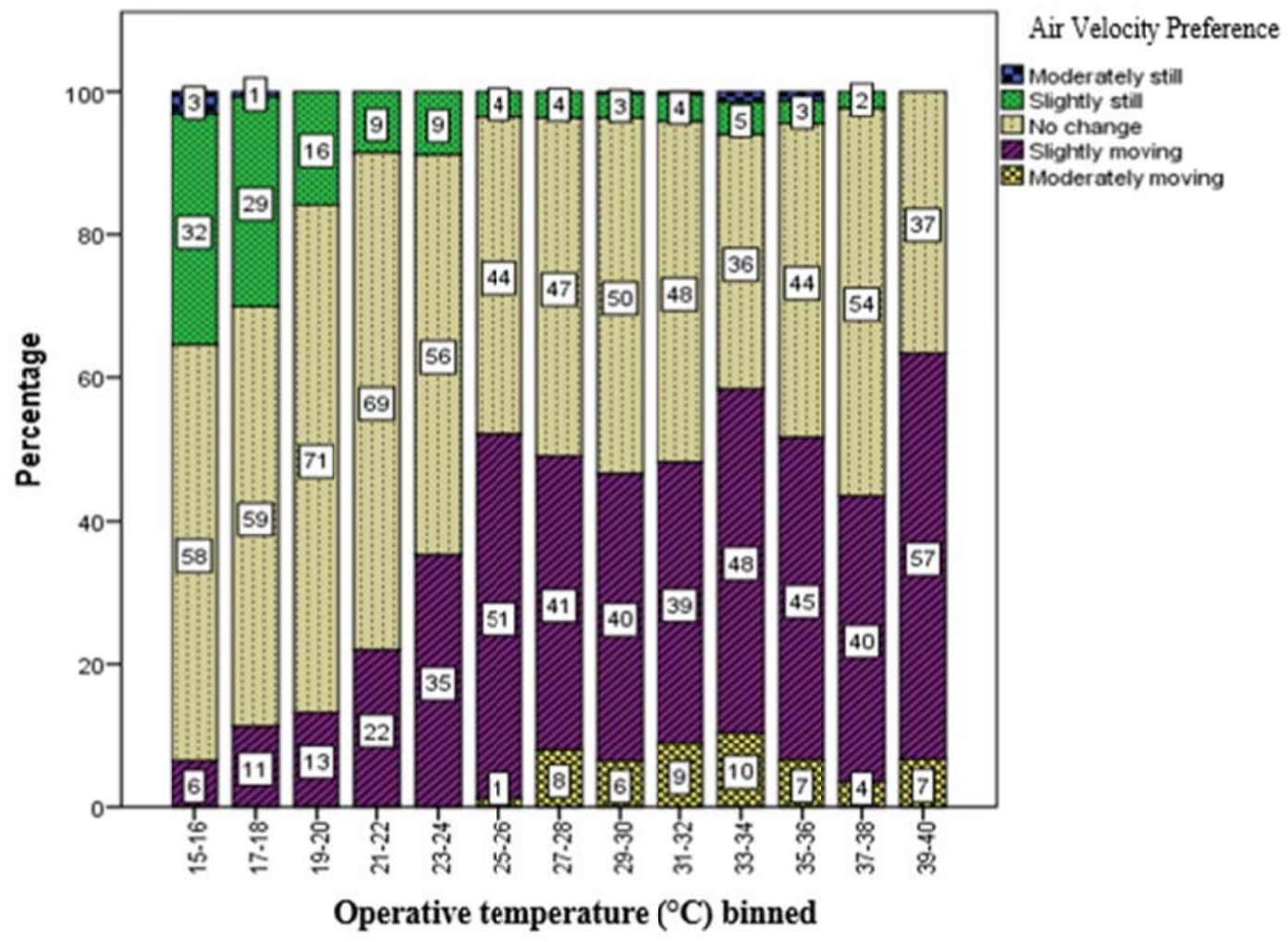

Figure 7 Distribution of the preference votes across air velocity over operative temperature (binned to $2{ }^{\circ} \mathrm{C}$ ) 


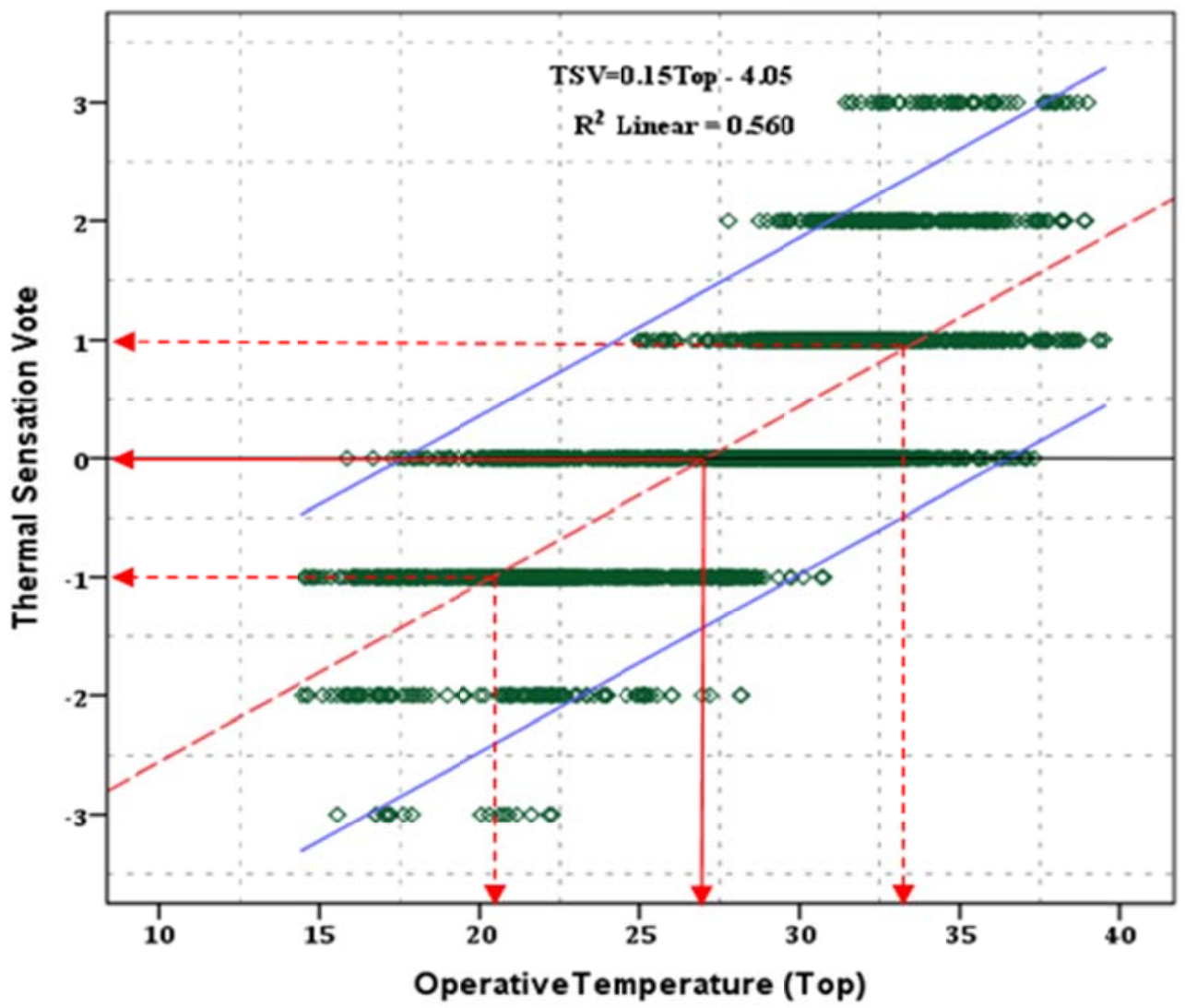

Figure 8 Linear regression of thermal sensation with indoor operative temperature (with $95 \%$ CI). 


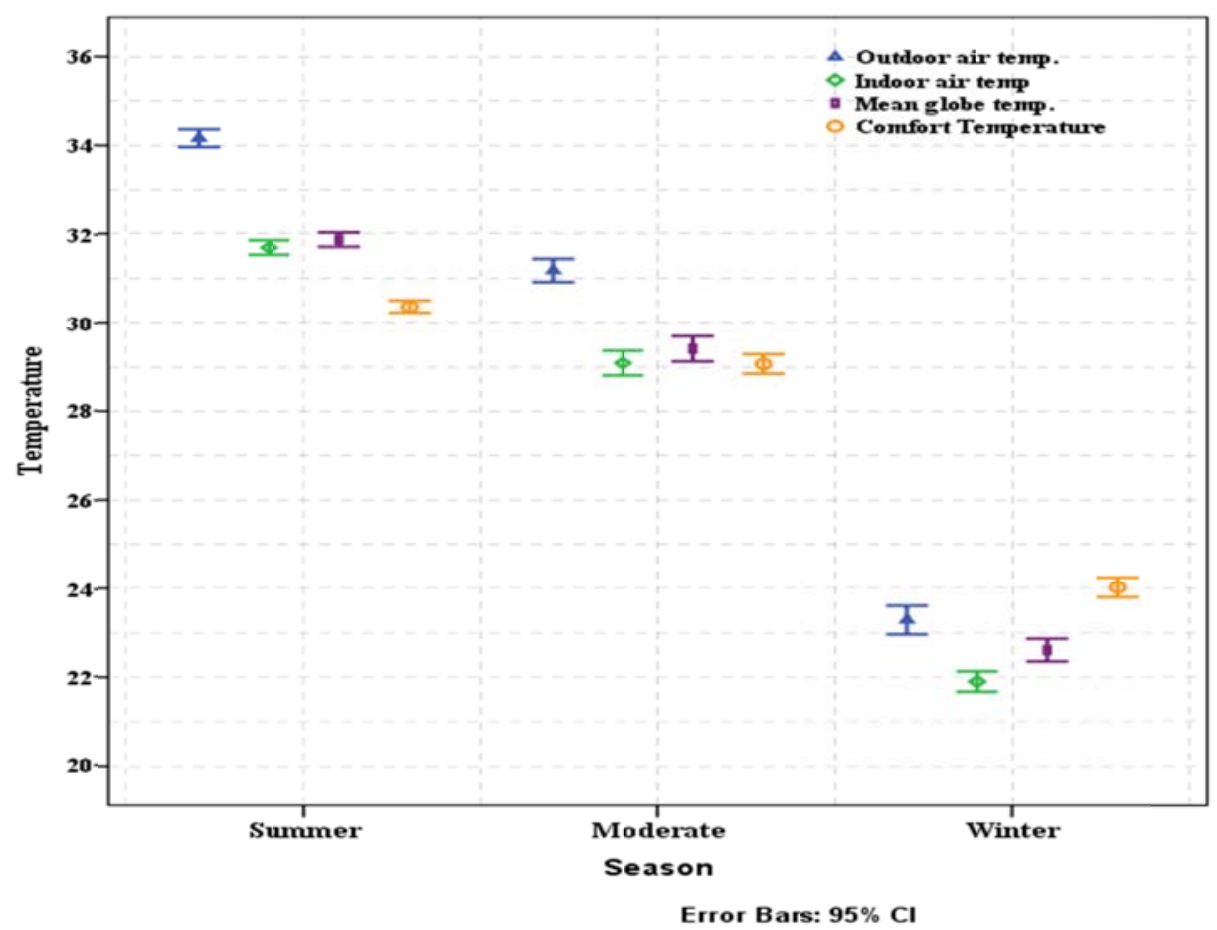

Figure 9 Seasonal variation of comfort temperature (Griffith constant $0.5{ }^{\circ} \mathrm{C}^{-1)}$ for naturally ventilated buildings (at 95\% CI) 


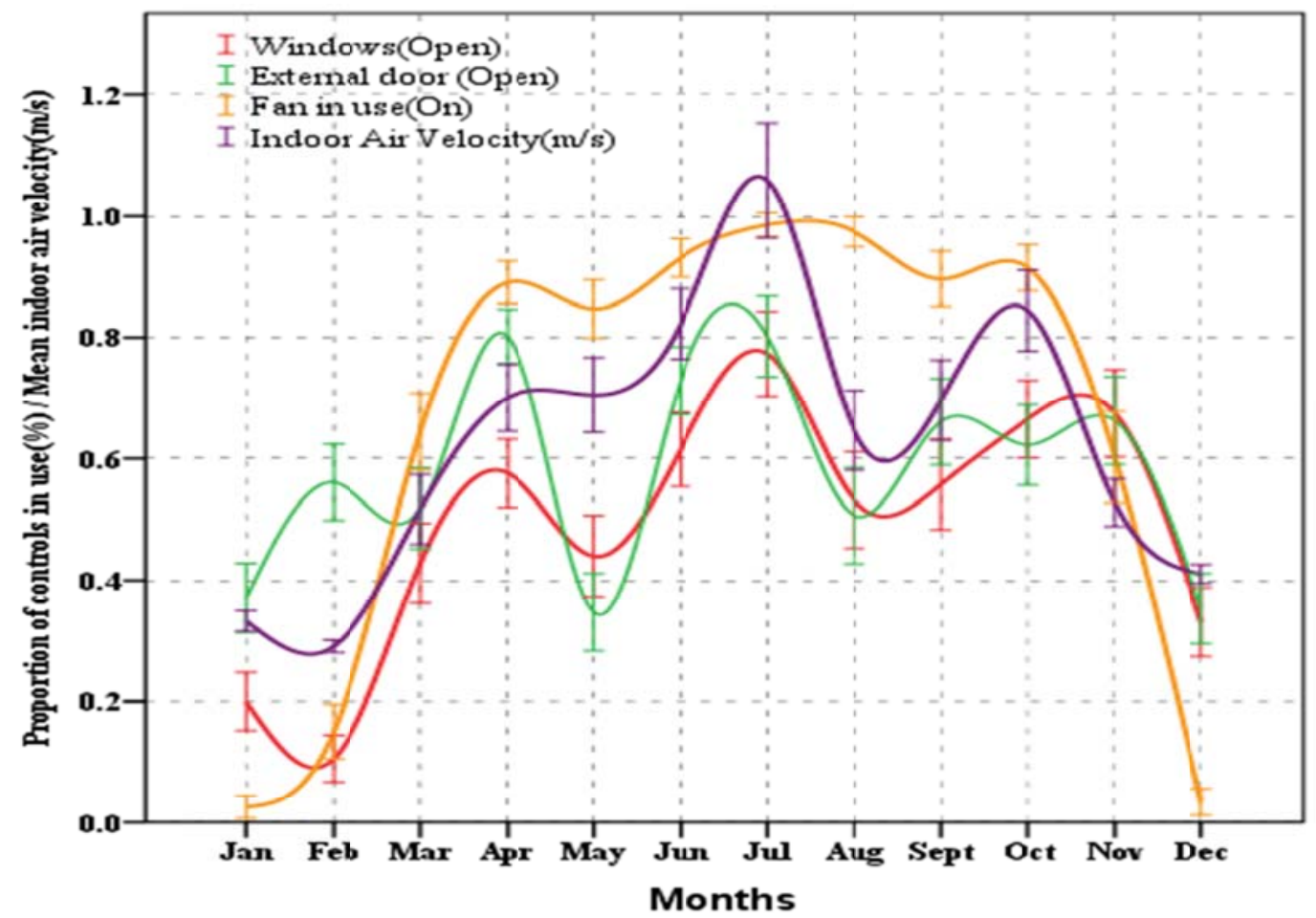

Error Bars: $95 \% \mathrm{Cl}$

Figure11 Proportion of controls in use and prevailing indoor mean air velocity for all seasons in naturally ventilated buildings. 


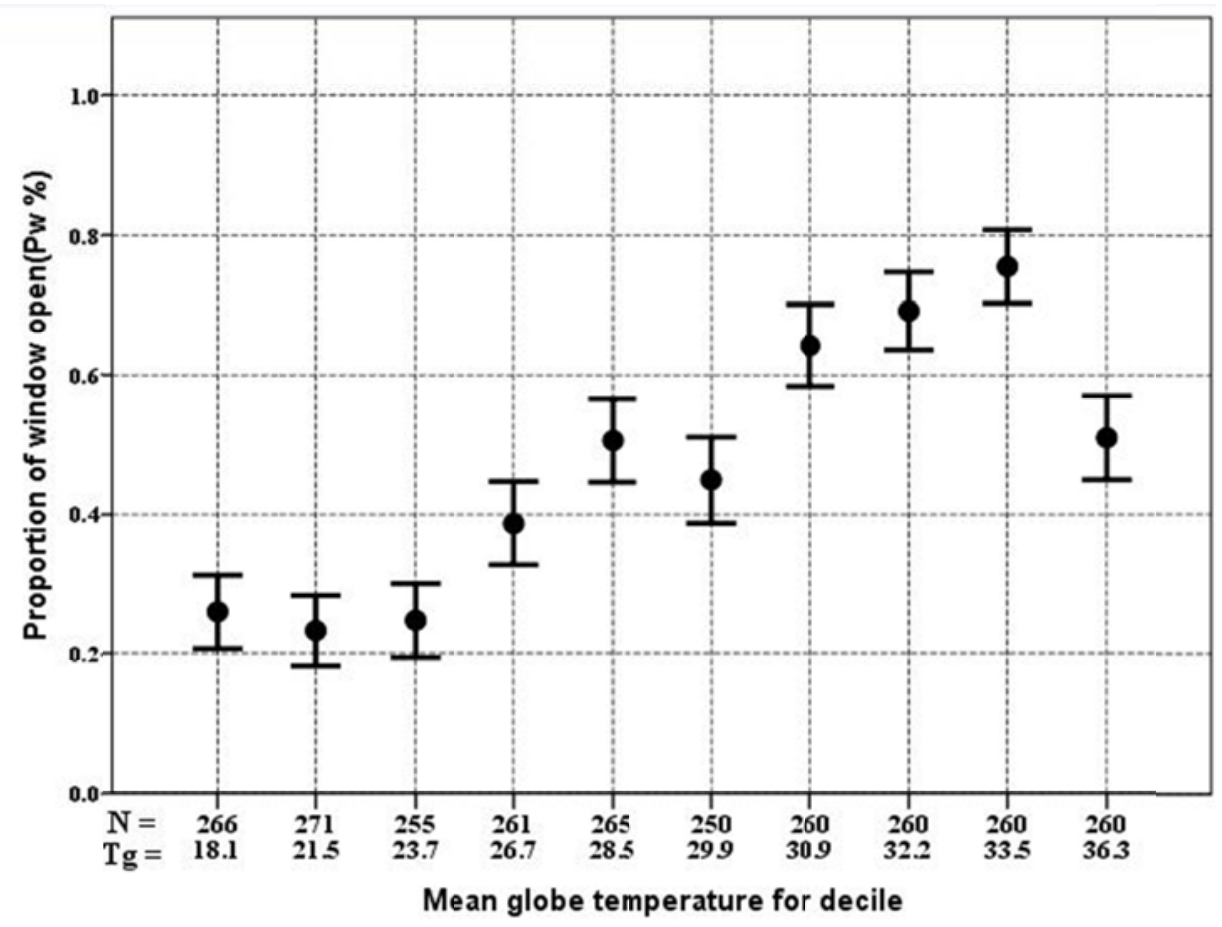

Error Bars: $95 \% \mathrm{Cl}$

(a)

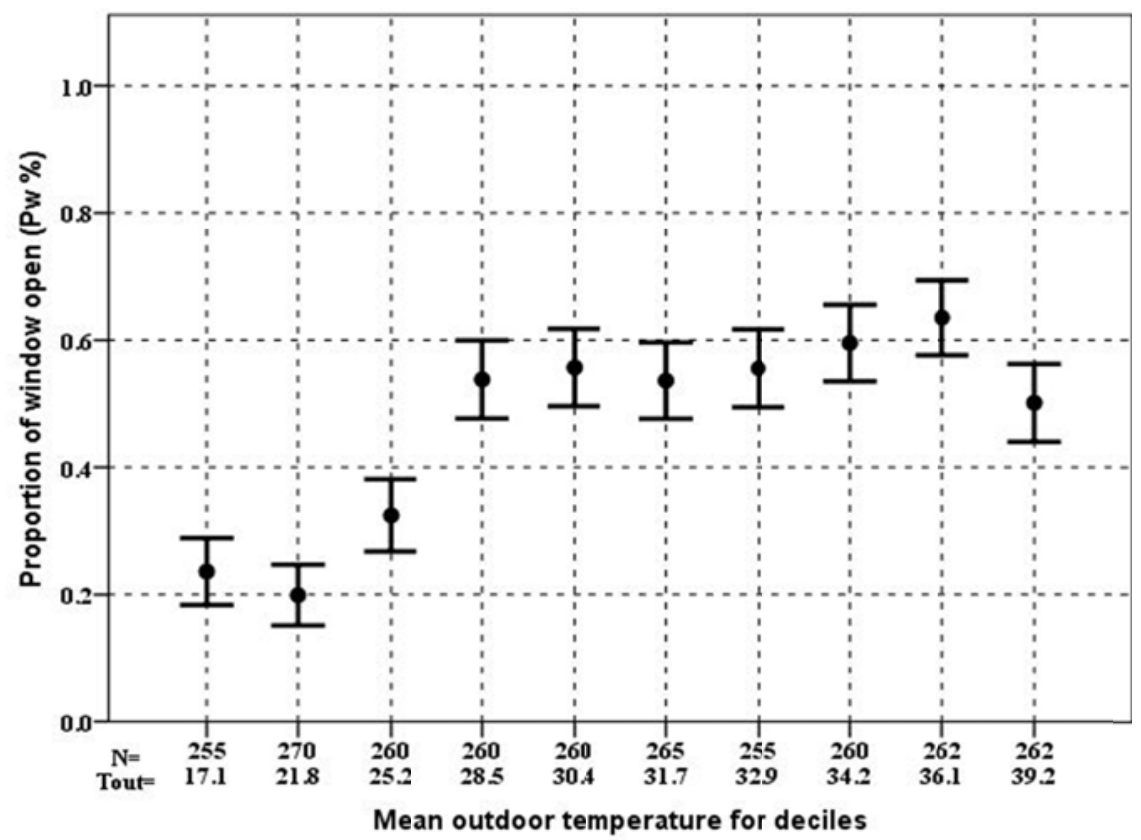

Error Bars: $95 \% \mathrm{Cl}$

(b)

Figure 12 Deciles of mean globe temperature (a) and mean outdoor temperature (b) with the proportion of 'windows open' in naturally ventilated buildings. 


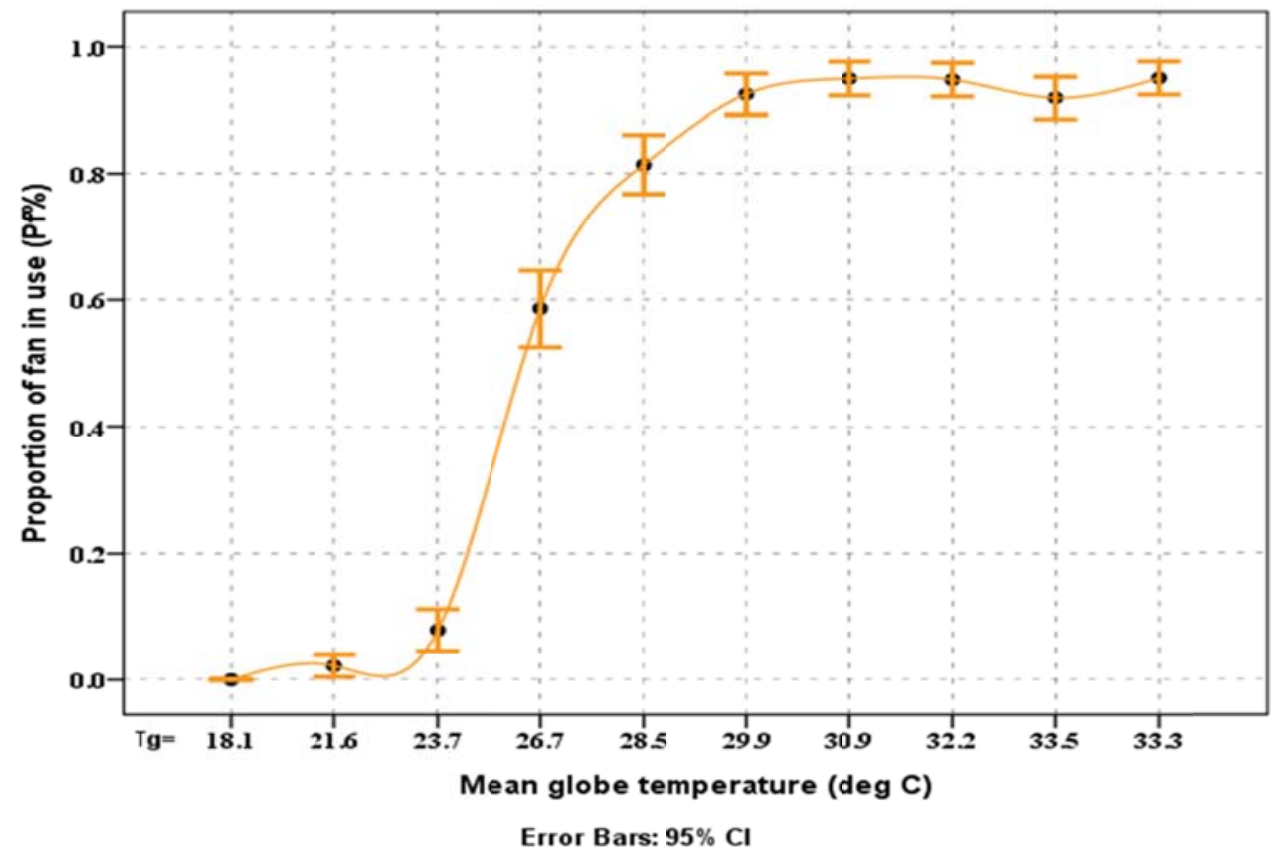

Figure 13 Deciles of mean globe temperature and the proportion of 'fans on' in naturally ventilated buildings. 